\title{
Beyond Bobby Jo Clary: The Unavailability of Same-Sex Marital Privileges Infringes the Rights of so Many More Than Criminal Defendants
}

\author{
Katharine T. Schaffzin ${ }^{*}$
}

\section{INTRODUCTION}

Perhaps too much has been written about the hypothetical scenario of a lesbian, gay, bisexual, or transgender criminal defendant being sentenced to death on the testimony of his or her same-sex spouse because a court determined that the marriage obtained validly in another jurisdiction was not a valid marriage in the current jurisdiction, rendering the marital privileges inapplicable. ${ }^{1}$ Actual case law on this subject does not exist, leading one to question the importance of speculation on an issue that has never arisen. With current speculation that the Supreme Court of the United States will mandate marriage equality at some point in the near future, ${ }^{2}$ it seems futile to continue to hypothesize about the

\footnotetext{
${ }^{*}$ Katharine T. Schaffzin is an Associate Professor and the Director of Faculty Development at the University of Memphis Cecil C. Humphreys School of Law. This article was made possible thanks to the support of the Law School, as well as the research assistance of Rachel N. Cade. The author thanks the faculty of the Law School for their helpful suggestions in shaping the direction of this article, as well as Daniel M. Schaffzin for his generous support.

1. See, e.g., Lisa Yurwit Bergstrom \& W. James Denvil, Availability of Spousal Privileges for Same-Sex Couples, 11 U. MD. L. J. RaCe, Religion, Gender \& Class 224, 239 (2011); Maria A. La Vita, Note, When the Honeymoon is Over: How a Federal Court's Denial of the Spousal Privilege to a Legally Married Same-Sex Couple Can Result in the Incarceration of a Spouse Who Refuses to Adversely Testify, 33 NEW ENG. J. ON CRIM. \& CIV. CONFINEMENT 243, 261 (2007).

2. See, e.g., Tanco v. Haslam, No. 3:13-CV-01159, 2014 WL 997525, at *9 (M.D. Tenn. Mar. 14, 2014) ("At this point, all signs indicate that, in the eyes of the United States Constitution, the plaintiffs' marriages will be placed on an equal footing with those of heterosexual couples and that proscriptions against same-sex marriage will soon become a footnote in the annals of American history."); Steve Sanders, Is the Full Faith and Credit Clause Still "Irrelevant" to Same-Sex Marriage?: Toward a Reconsideration of the Conventional Wisdom, 89 IND. L.J. 95, 99-100 (2014) (implying that constitutionally mandated marriage equality is inevitable, but noting that it is still "some years off").
} 
effect of marriage inequality on potential lesbian, gay, bisexual, and transgender criminal defendants.

One recent case, however, has come close to raising the previously hypothetical issue and sheds light on the fact that the denial of marital privileges to same-sex spouses has significant repercussions for all samesex couples in the United States. ${ }^{3}$ In August 2013, a Kentucky trial court heard arguments in Kentucky v. Clary on the applicability of Kentucky's spousal testimony privilege where the relationship between Bobby Jo Clary, the criminal defendant charged with murder, ${ }^{4}$ and Geneva Case, a witness subpoenaed by the prosecution, ${ }^{5}$ constituted a civil union celebrated in Vermont before that state began issuing marriage licenses to same-sex couples. ${ }^{6}$ Defense counsel argued that a Kentucky

3. See Kentucky v. Clary, No. 11-CR-3329 (Ky. Cir. Ct. Sept. 23, 2013), available at http://img1.wikia.nocookie.net/_cb20130924152729/marriage/images/6/65/Commonwealth_v._Cla ry_Order_2013-09-23.pdf (order denying witness' motion to quash the Commonwealth's subpoena requiring her to testify against her same-sex partner, who was being tried for murder, and the defendant-partner's motion to invoke the marital privilege).

4. On October 30, 2011, Louisville Metro Police discovered the body of 64-year-old George Murphy dead in his Kentucky home. POLICE: Louisville Woman Killed Man, Stole Truck, WDRB.COM, http://www.wdrb.com/story/15913998/police-louisville-woman-killed-man-stoletruck? clienttype=printable (last updated Nov. 01, 2011). The Jefferson County Coroner concluded that he "died of injuries to his head, neck, and extremities" inflicted during an assault. Id. Police arrested Bobbie Jo Clary, a family friend of Murphy's, for his murder and the subsequent theft of his truck. Id.

5. According to prosecutors, Clary recounted the events surrounding Murphy's death to her partner, Geneva Case. Clary, No. 11-CR-3329 at 1. Accordingly, the Jefferson County Prosecutor's Office subpoenaed Case to testify at Clary's trial. Id. Clary invoked Kentucky's spousal testimony privilege and Case moved to quash the subpoena in light of that same privilege. Id. at 1-2. Kentucky's spousal testimony privilege is statutorily defined as Kentucky's "Husband-wife privilege," which includes:

(a) Spousal testimony. The spouse of a party has a privilege to refuse to testify against the party as to events occurring after the date of their marriage. A party has a privilege to prevent his or her spouse from testifying against the party as to events occurring after the date of their marriage.

KY. R. EVID. 504(a).

6. Clary, No. 11-CR-3329 at 2 (quoting Ky. R. EvID. 504(a)). At a hearing on the motion to quash the subpoena, the Jefferson County Prosecutor's Office took the position that Kentucky's marital privileges do not apply to same-sex couples. See Colleen Curry, Lesbian May Be Forced to Testify Against Wife, ABC NEWs (Aug. 1, 2013), http://abcnews.go.com/US/lesbian-woman-forcedtestify-wifes-murder-trial/print?id=19828792. Vermont granted a civil union to the couple in 2004, before that State recognized same-sex marriages. Clary, No. 11-CR-3329 at 4. Prosecutors relied on the State's mini-DOMA - a constitutional amendment passed by referendum in 2004 prohibiting the State from recognizing same-sex marriages or civil unions celebrated in other jurisdictions - in support of its position. See Curry, supra. The pertinent constitutional provision provides that "[o]nly a marriage between one man and one woman shall be valid or recognized as a marriage in Kentucky. A legal status identical or substantially similar to that of marriage for unmarried 
constitutional amendment - providing that the State would not recognize marriages between same-sex individuals whether validly celebrated in another state or not (known as a "mini-DOMA") — was unconstitutional. However, the trial judge did not reach that issue, denying the applicability of spousal immunity instead because the defendant and the witness were not validly married, even in Vermont; rather, they had a civil union. ${ }^{8}$ While the facts of the Clary case do not fulfill the dreams of those authors discussing such hypotheticals, ${ }^{9}$ they came closer than ever before.

Clary may be a dead end for the argument that hypothetical lesbian, gay, bisexual, and transgender criminal defendants need protection from the possibility that their same-sex spouses from marriages validly celebrated in a state other than that in which they are on trial will be forced to reveal damning evidence on the stand, possibly leading to conviction and likely resulting in the destruction of the marriage. The fact that such cases have simply failed to materialize demonstrates that the risk of such a scenario is extremely low. ${ }^{10}$ Nonetheless, the effect of

individuals shall not be valid or recognized.” KY. CONST. §233A, invalidated by Love v. Beshear, 989 F. Supp. 2d 536, 550 (W.D. Ky. 2014). Notably, the Kentucky Attorney General's Office declined a request from the circuit court judge to argue on behalf of prosecutors. See Associated Press, Ky. AG Staying Out of Same Sex Privilege Issue, WUKY.org (Aug. 16, 2013), http://www.wuky.org/post/ky-ag-staying-out-same-sex-privilege-issue.

7. See Curry, supra note 6. Kentucky recognizes both marital privileges. KY. R. EvID. 504. Rule 504 provides:

(a) Spousal testimony. The spouse of a party has a privilege to refuse to testify against the party as to events occurring after the date of their marriage. A party has a privilege to prevent his or her spouse from testifying against the party as to events occurring after the date of their marriage.

(b) Marital communications. An individual has a privilege to refuse to testify and to prevent another from testifying to any confidential communication made by the individual to his or her spouse during their marriage. The privilege may be asserted only by the individual holding the privilege or by the holder's guardian, conservator, or personal representative. A communication is confidential if it is made privately by an individual to his or her spouse and is not intended for disclosure to any other person.

Id. Notably, for comparison's sake, Kentucky recognizes common law marriages celebrated outside Kentucky as valid marriages, although it does not recognize common law marriages celebrated within the State. See Curry, supra note 6.

8. Clary, No. 11-CR-3329 at 6.

9. Cf., e.g., Bergstrom \& Denvil, supra note 1, at 229-57 (providing hypotheses and discussion about the availability of marital privileges); La Vita, supra note 1, at 261 ("if evidence derived from marital communications is allowed and weighs heavily toward a conviction, a samesex spouse may be convicted and incarcerated in a circumstance where she may not have been if the evidence was privileged").

10. Although, arguably, the risk increases as the number of valid same-sex marriages 
inconsistent marriage laws on the application of marital privileges is real and arguably affects every same-sex spouse in the United States. ${ }^{11}$ These effects are magnified by the growing number of same-sex spouses in America. ${ }^{12}$

Lesbian, gay, bisexual, and transgender criminal defendants who spill the beans to their same-gender spouses are not the only citizens affected by a state's refusal to apply marital privileges to same-sex spouses. In fact, every same-sex spouse in the United States is adversely affected by the application of laws refusing to recognize the validity of a same-sex marriage celebrated in another state to deny them marital privileges. ${ }^{13}$ This is because the risk of denial of an evidentiary privilege in one state would have a chilling effect on the behavior the privilege is intended to protect in the state celebrating the marriage. ${ }^{14}$ The lack of certainty over whether the marital privileges will be applied across state lines would prevent one same-sex spouse in certain circumstances from openly communicating with the other for fear that such communications will be revealed in court. ${ }^{15}$ Thus, the privilege protected in one state is defeated in the next. ${ }^{16}$ And the behavior protected by the privilege in one state will be curtailed for fear of compelled testimony in another state. ${ }^{17}$ Essentially, one state's laws refusing to recognize valid same-sex marriages have the effect of partially invalidating the laws of another state celebrating marriage equality. ${ }^{18}$

With the number of states celebrating same-sex marriage growing almost monthly, ${ }^{19}$ the number of those affected by the denial of marital privileges continues to grow exponentially. Many states, however, continue to support their statutes and constitutional amendments reaffirming their rights to refuse to recognize as valid a same-sex marriage obtained validly in another state. ${ }^{20}$ Kentucky's mini-DOMA,

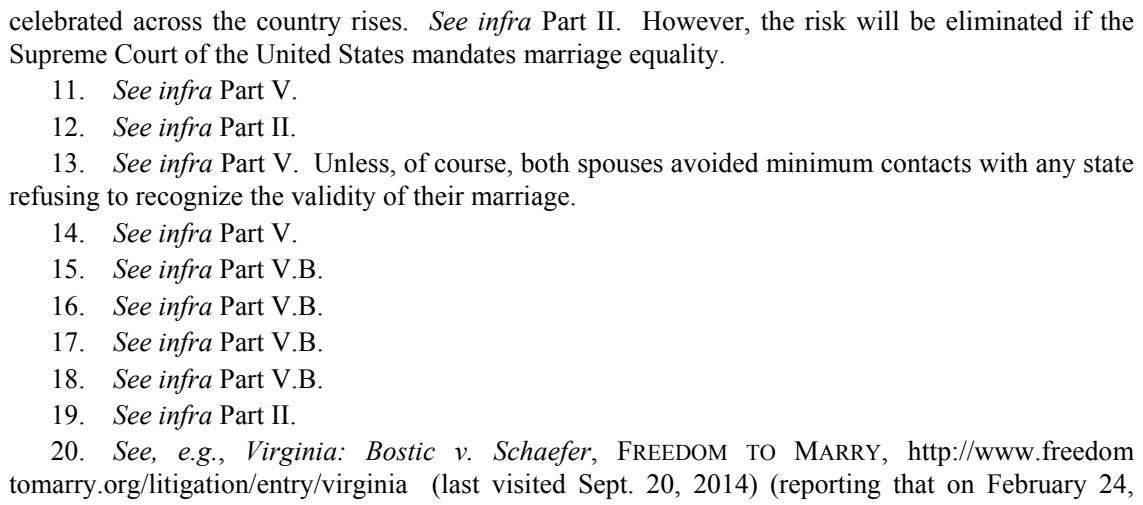


like that in many states, is backed up by a similar provision in the federal Defense of Marriage Act (DOMA). ${ }^{21}$ Although $\S 3$ of DOMA was deemed unconstitutional in United States v. Windsor, ${ }^{22} \S 2$ - the provision allowing states to define marriage based on the gender of those entering into it-was not discussed in that case and remains good law. In $\S 2$, DOMA provides:

No State, territory, or possession of the United States, or Indian tribe, shall be required to give effect to any public act, record, or judicial proceeding of any other State, territory, possession, or tribe respecting a relationship between persons of the same sex that is treated as a marriage under the laws of such other State, territory ${ }_{33}$ possession, or tribe, or a right or claim arising from such relationship.

The reality that the Supreme Court has struck $\S 3$ as unconstitutional while $\S 2$ persists creates a tension that has not yet been resolved.

This article explores the impact of $\S 2$ of DOMA and mini-DOMAs on the actions of same-sex spouses in their home states, which would be protected from disclosure in those states, but which may be ordered revealed by a foreign court with a mini-DOMA. ${ }^{24}$ For example, it will explore how a mini-DOMA in Texas may inhibit the lawful and protected actions of same-sex spouses in New York, and why that result defeats the intent of lawmakers in New York. ${ }^{25}$ Part II presents an

2014, defendants in Bostic v. Rainey, 970 F. Supp. 2d 456 (E.D. Va. 2014), aff'd, Bostic v. Schaefer, Nos. 14-1167, 14-1169, 14-1173, 2014 WL 3702493 (4th Cir. Jul. 28, 2014), filed an appeal from order striking Virginia's mini-DOMA as unconstitutional, in which the Fourth Circuit ultimately affirmed the district court's ruling that the mini-DOMA was unconstitutional); Joseph Lord, Kentucky Gov. Steve Beshear to Appeal Federal Judge's Same-Sex Marriage Order, WFPL NEWS (Mar. 4, 2014, 11:00 AM), http://wfpl.org/post/kentucky-gov-steve-beshear-appeal-federal-judgessame-sex-marriage-order (reporting that Kentucky governor intends to appeal from the decision in Love v. Beshear, 989 F. Supp. 2d 536 (W.D. Ky. 2014) striking Kentucky’s mini-DOMA as unconstitutional); Oklahoma: Bishop v. Smith, FREEDOM TO MARRY, http://www.freedom tomarry.org/litigation/entry/oklahoma (last visited Sept. 20, 2014) (reporting that Oklahoma filed an appeal on January 16, 2014, from the decision in Bishop v. United States ex rel. Holder, 962 F. Supp. 2d 1252 (N.D. Okla. 2014), aff'd, Bishop v. Smith, Nos. 14-5003, 14-5006, 2014 WL 3537847 (10th Cir. 2014) striking Oklahoma's mini-DOMA as unconstitutional); Utah: Kitchen v. Herbert, FREEDOM TO MARRY, http://www.freedomtomarry.org/litigation/entry/utah (last visited Sept. 20, 2014) (reporting that Utah appealed from order striking Utah's mini-DOMA as unconstitutional in Kitchen v. Herbert, 961 F. Supp. 2d 1181 (D. Utah 2013), aff'd, 755 F.3d 1193 (10th Cir. 2014)).

21. See 28 U.S.C. $§ 1738 C$ (2012), invalidated in part by United States v. Windsor, 133 S. Ct. 2675 (2013).

22. 133 S. Ct. at 2696.

23. 28 U.S.C. $\S 1738$ C.

24. See infra Part V.

25. See infra Part V.B. 
overview of the quickly changing landscape of same-sex marriage in the United States. ${ }^{26}$ Next, Part III explains marital privileges generally, focusing on the confidential marital communications privilege, the spousal testimony privilege, and the role of Federal Rule of Evidence 501 in applying those privileges. ${ }^{27}$ Part IV addresses the applicability of marital privileges in federal court since the Supreme Court's 2013 decision in United States $v$. Windsor ${ }^{28}$ Part V assesses the inequality of the marital privileges afforded to same-sex couples when compared to opposite-sex couples under $\S 2$ of DOMA, as well as mini-DOMAs. ${ }^{29}$ Part VI suggests the options available to correct the disparities between same-sex couples and opposite-sex couples in exercising the benefits associated with marital privileges, including a uniform marital privilege and intervention by the Supreme Court. ${ }^{30}$ Part VI includes an explanation and assessment of available constitutional arguments challenging DOMA $\S 2$ and mini-DOMAs, including equal protection, substantive due process, and comity. ${ }^{31}$ Finally, Part VII concludes that the unequal application of marital privileges to same-sex spouses renders DOMA $\S 2$ and states' mini-DOMAs unconstitutional, requiring action from the Supreme Court to ensure the uniformity needed to allow samesex spouses to fully enjoy the benefits of marriage conferred upon them by the laws of the state of their marriage celebration. ${ }^{32}$

\section{A GROWING POPULATION}

The state of same-sex marriages has changed drastically since the demise of $\S 3$ of the federal DOMA, which limited the federal definition of marriage to one man and one woman, in the now infamous 2013 case of United States v. Windsor. ${ }^{33}$ But long before Edith Windsor had her day in court, the United States was facing a turn in the way individuals viewed the fundamental right to marry. One of the first cases dealing with same-sex couples' right to marry, Baker v. Nelson, ${ }^{34}$ resulted in an

\footnotetext{
26. See infra Part II.

27. See infra Part III.

28. See infra Part IV.

29. See infra Part V.

30. See infra Part VI.

31. See infra Part VI.

32. See infra Part VII

33. 133 S. Ct. 2675 (2013).

34. 191 N.W.2d 185 (Minn. 1971), appeal dismissed, 409 U.S. 810 (1972).
} 
unceremonious dismissal by the Supreme Court, ${ }^{35}$ which has been long cited by both those in opposition and support of same-sex marriages. ${ }^{36}$ In 1971, Richard John Baker and James Michael McConnell, a gay couple, applied to a court clerk in Minneapolis, Minnesota, for a marriage license. ${ }^{37}$ The couple was turned away because state law limited marriages to persons of the opposite sex. ${ }^{38}$ The couple argued that the United States Constitution protected a fundamental right to marry. ${ }^{39}$ A judge in Minnesota disagreed with the couple and instead concluded that the clerk was not required to issue a marriage license to the couple. ${ }^{40}$ The Minnesota Supreme Court upheld that ruling, asserting that "marriage [i]s a union of man and woman" in an institution "as old as the book of Genesis." 41 Most notably, the Supreme Court dismissed the appeal with this one-sentence order: "The appeal is dismissed for want of a substantial federal question." 42

In stark contrast to 1971, today some same-sex couples enjoy explicit rights and protections in a growing number of states. Unfortunately, there is no hard or fast rule governing the extent of rights enjoyed by same-sex couples; some states allow same-sex couples rights equal to heterosexual couples to marry, while others allow more limited recognition of same-sex marriages. ${ }^{43}$ Twenty states and the District of Columbia recognize same sex marriages, ${ }^{44}$ one state recognizes civil

35. See Baker, 409 U.S. at 810.

36. Lyle Denniston, Gay Marriage and Baker v. Nelson, SCotusBlog (July 4, 2012, 4:52 PM), http://www.scotusblog.com/2012/07/gay-marriage-and-baker-v-nelson/ ("The precedent is considered to be fully binding even now by opponents of same-sex marriage, but of only limited impact — at most—by advocates of such marriages.").

37. Baker, 191 N.W.2d at 185.

38. Id.

39. Id. at 186 .

40. Id. at 185 .

41. Id. at 186 .

42. Baker v. Nelson, 409 U.S. 810 (1972).

43. Compare Goodridge v. Dep’t of Pub. Health, 798 N.E.2d 941, 968-70 (Mass. 2003) (holding that the Massachusetts ban on same-sex marriages violated individual liberty and equality safeguards of the Massachusetts Constitution, and thus invalidating the ban), with WIS. STAT. ANN. $\S 770.001$ (West 2013) (establishing domestic partnerships and stating that a domestic partnership "is not substantially similar to [the status] of marriage").

44. Those states recognizing same-sex marriage include: California, Hollingsworth v. Perry, 133 S. Ct. 2652 (2013); Connecticut, Conn. Gen. Stat. AnN. § 46b-20a (West 2014); District of Columbia, D.C. Code $\S 46-401$ (Supp. 2014); Delaware, Del. Code ANN. tit. 13, § 101 (West Supp. 2014); Hawaii, HaW. Rev. Stat. ANN. § 572-1 (West Supp. 2013); Illinois, 750 Ill. Comp. STAT. AnN. 5/201 (West 2009); Iowa, Varnum v. Brien, 763 N.W.2d 862 (Iowa 2009); Maine, Me. ReV. Stat. ANN. tit. 19-A, § 650-A (Supp. 2013); Maryland, MD. CodE ANN. FAM. LAW § 2-201 (West Supp. 2013); Massachusetts, Goodridge, 798 N.E.2d 941; Minnesota, Minn. STAT. AnN. $§ 517.01$ 
unions, ${ }^{45}$ and four states recognize domestic partnerships and some protections enjoyed by heterosexual married couples. ${ }^{46}$ Twelve states have stayed rulings to allow same-sex marriages pending appeals. ${ }^{47}$

The status of marriage equality across the nation changes every day with each new court that addresses the issue. For example, on Friday, March 14, 2014, the United States District Court for the Middle District

(West Supp. 2014); Oregon, Geiger v. Kitzhaber, 994 F. Supp. 2d 1128 (D. Or. 2014); New Hampshire, N.H. Rev. StAT. ANN. §457:1-a (Supp. 2013); New Jersey, Garden State Equal. v. Dow, 82 A.3d 336 (N.J. Super. Ct. Law Div. 2013); New Mexico, Griego v. Oliver, 316 P.3d 865 (N.M. 2013); New York, N.Y. Dom. ReL. LAW § 10-a (McKinney Supp. 2014); Pennsylvania, Whitewood v. Wolf, 992 F. Supp. 2d 410 (M.D. Pa. 2014); Rhode Island, R.I. GEN. LAWs ANN. § 15-1-1 (West Supp. 2014); Vermont, VT. STAT. ANN. tit. 15, § 8 (West Supp. 2013); Virginia, Bostic v. Schaefer, Nos. 14-1167, 14-1169, 14-1173, 2014 WL 3702493 (4th Cir. July 28, 2014); Washington, WASH. REV. CODE ANN. § 26.04.010 (West Supp. 2014). 2013).

45. Colorado provides for civil unions. Colo. Rev. Stat. AnN. § 14-15-102 (West Supp.

46. Those states recognizing domestic partnerships and some of the privileges enjoyed by opposite-sex married couples are: Nevada, NEV. REV. STAT. ANN. $\S \S 122 \mathrm{~A} .100$ to .510 (West 2013); Oregon, OR. ReV. STAT. ANN. § 106.340 (West Supp. 2014); Washington, WASH. ReV. Code ANN. $\S \S 26.60 .030$ (West Supp. 2014) (altered in 2012 to make domestic partnerships available if at least one partner is sixty-two or older); Wisconsin, Wis. STAT. ANN. $\S \S 770.001,770.05$ (West Supp. 2013); Wis. STAT. ANN. § 905.05 (West Supp. 2013).

47. Arkansas, Wright v. Arkansas, No. 60CV-13-2662, 2014 WL 1908815 (Ark. Cir. Ct. May 9, 2014) (holding Arkansas' constitutional amendment discriminatory and allowing same-sex marriages; stayed pending State's appeal); Colorado, Burns v. Hickenlooper, No. 14-cv-01817-RMKLM, 2014 WL 3634834 (D. Colo. July 23, 2014) (pending the Tenth Circuit Court of Appeals); Brinkman v. Long, No. 13-CV-32572, 2014 WL 3408024 (D. Colo. July 9, 2014) (ruling in state court in favor of same-sex marriages, stayed by the Colorado Supreme Court pending appeal to be heard later this year); Florida, Brenner v. Scott, Nos. 4:14cv107-RH/CAS, 4:14cv138-RH/CAS, 2014 WL 4113100 (N.D. Fla. Aug. 21, 2014) (pending appeal to the Tenth Circuit); Idaho, Latta v. Otter, No. 1:13-cv-00482-CWD, 2014 WL 1909999 (D. Idaho May 13, 2014) (pending appeal of the Ninth Circuit Court of Appeals, arguments set to be heard Sept. 8, 2014); Indiana, Baskin v. Bogan, No. 1:14-cv-00355-RLY-TAB1:14-cv-00404-RLY-TAB, 1:14-cv-00406-RLY-MJD, 2014 WL 2884868 (S.D. Ind. June 25, 2014), aff'd, Nos. 14-2386, 14-2387, 14-2388, 14-2526, 2014 WL 4359059 (7th Cir. Sept. 4, 2014) (pending appeal to the United States Supreme Court); Kentucky, Bourke v. Beshear, No. 3:13-CV-750-H, 2014 WL 556729 (W.D. Ky. Feb. 12, 2014) (pending appeal of the Sixth Circuit Court of Appeals, the Kentucky Attorney General refused to defend the constitutional ban and Kentucky Governor hired private counsel to defend); Michigan, DeBoer v. Snyder, 973 F. Supp. 2d 757 (E.D. Mich. 2014) (pending appeal of the Sixth Circuit Court of Appeals); Oklahoma, Bishop v. Smith, Nos. 14-5003, 14-5006, 2014 WL 3537847 (10th Cir. July 18,2014 ) (upholding the district court's striking the unconstitutional ban on same-sex marriages, the 10th Circuit Court of Appeals has issued a stayed pending appeal of the United States Supreme Court); Tennessee, Tanco v. Haslam, No. 3:13-cv-01159, 2014 WL 997525 (M.D. Tenn. Mar. 14, 2014) (order granting preliminary injunction, pending appeal of the Sixth Circuit Court of Appeals); Texas, De Leon v. Perry, 975 F. Supp. 2d 632 (W.D. Tex. 2014) (pending appeal of the Fifth Circuit Court of Appeals); Utah, Kitchen v. Herbert, 755 F.3d 1193 (10th Cir. 2014) (Tenth Circuit affirmed Utah district court's invalidation of same-sex marriage ban pending disposition of writ of certiorari); Wisconsin, Wolf v. Walker, No. 14-cv-64-bbc, 2014 WL 2693963 (W.D. Wis. June 13, 2014), aff'd, Baskin, 2014 WL 4359059 (7th Cir. Sept. 4, 2014) (pending appeal to the United States Supreme Court). 
of Tennessee issued an injunction against the state's ban on same-sex marriage to recognize the marriages of three same-sex couples validly married in states that celebrate same-sex marriages. ${ }^{48}$ Judge Aleta A. Trauger noted in her order that, "[a]t this point, all signs indicate that, in the eyes of the United States Constitution, the plaintiffs' marriages will be placed on an equal footing with those of heterosexual couples and that proscriptions against same-sex marriage will soon become a footnote in the annals of American history." 49 While this historical injunction is not unique, it does draw the question of what rights legally married individuals of one state will receive in another that might not recognize their marriage.

While it does seem inevitable at this point that the Supreme Court will eventually take action to mandate marriage equality, the issue of marriage inequity remains pertinent because the Court has already "ducked the issue" of the constitutionality of $\S 2$ of DOMA in Hollingsworth v. Perry, ${ }^{50}$ and Justice Sotomayor has "indicated she might prefer to let the question of state gay marriage laws 'perk' for a while longer in the lower courts." ${ }^{, 51}$ Because universal marriage equality may be years off, the discussion of the implications of non-uniform state laws on same-sex marriage post-Windsor remains relevant. ${ }^{52}$

\section{MARITAL PRIVILEGES}

All state and federal courts recognize a marital privilege in one form or another. ${ }^{53}$ These privileges are reserved to those who have either currently or previously entered into a valid marriage. ${ }^{54}$ As evidenced in

48. Tanco, $2014 \mathrm{WL} 997525$, at $* 9$ (order granting preliminary injunction). See also Heidi Hall, Judge recognizes gay marriages of 3 Tennessee couples, USA TODAY (Mar. 14, 2014), http://www.usatoday.com/story/news/nation/2014/03/14/gay-marriage-tennessee-lawsuit/6432547/.

49. Tanco, $2014 \mathrm{WL} 997525$, at *9.

50. See Hollingsworth v. Perry, 133 S. Ct. 2652, 2668 (2013) (deciding the case on standing grounds).

51. Sanders, supra note 2, at 100.

52. See id. (discussing importance of same-sex marriage rights and privileges given that "constitutionally mandated marriage equality. . . is some years off").

53. See infra notes 63,86 and accompanying text.

54. To apply, each privilege requires a valid marriage; in determining if a marital privilege will apply, "[a] trial court must first determine whether a spouse could assert a marital privilege.... Then, because only a spouse may assert the privilege, the court determines whether the party or witness qualifies as a spouse." Bergstrom \& Denvil, supra note 1, at 237. See also Sally A. Roberts, Spousal Privileges: "Honey, the Judge Says We're History!", THE LAW OfFICES OF SALly A. ROBERTS, LLC, http://www.sallyrobertslegal.com/personal-injury-articles.htm (last visited Sept. $20,2014)$ (discussing martial privileges and their application). 
Part II, what constitutes a valid marriage is a fairly unpredictable question these days that depends on who you ask and where he is standing. ${ }^{55}$ Who is entitled to exercise a marital privilege - and whereis similarly unpredictable.

Evidentiary rules are constructed to aid the fact finder in discovering the truth. ${ }^{56}$ Privileges are antithetical to this endeavor. Specifically, privileges protect from disclosure relevant, otherwise admissible evidence that may bring a jury closer to the truth. ${ }^{57}$ The purpose of obstructing that search for the truth with an evidentiary privilege is to protect some other public interest deemed more important than the discovery of the truth. ${ }^{58}$ Thus, for a variety of public policy reasons, a number of evidentiary privileges have evolved, including marital privileges. There are two marital privileges and they both focus on protecting the relationship between spouses: the spousal testimony privilege and the confidential marital communications privilege. ${ }^{59}$

Both marital privileges require a valid marriage as a pre-requisite to their application. ${ }^{60}$ Because, like all evidentiary privileges, marital privileges are "in derogation of the truth,... the 'valid marriage' requirement must be interpreted strictly." ${ }^{16}$ Nonetheless, the public

55. See supra Part II.

56. See Roberts, supra note 54, at 1.

57. See id.

58. See id. at 1-2 (citing Kimberly A. Connor, A Critique of the Marital Privileges: An Examination of the Marital Privileges in the United States Military Through the State and Federal Approaches to the Marital Privileges, 36 VAL. U. L. REV. 119, 131 (2001)).

59. See, e.g., United States v. Knox, 124 F.3d 1360, 1365 (10th Cir. 1997) (recognizing the two privileges); United States v. Acker, 52 F.3d 509, 514 (4th Cir. 1995) (same); United States v. Lustig, 555 F.2d 737, 747 (9th Cir. 1977) (same).

60. See, e.g., Knox, 124 F.3d at 1365; Acker, 52 F.3d at 515; Lustig, 555 F.2d at 747 (citing United States v. Apodaca, 522 F.2d 568, 571 (10th Cir. 1975); United States v. Neeley, 475 F.2d 1136, 1137 (4th Cir. 1973)).

61. Acker, 52 F.3d at 515 (citing United States v. Hamilton, 19 F.3d 350, 354 (7th Cir. 1994)). See also Trammel v. United States, 445 U.S. 40, 50 (1980) ("[privileges] must be strictly construed"). In Acker, the United States Court of Appeals for the Fourth Circuit affirmed the refusal of the United States District Court for the Western District of North Carolina to recognize defendant Catherine Acker's assertion of either the spousal testimony privilege or the confidential marital communications privilege. 52 F.3d at 515. In that case, Acker was convicted of bank robbery after Samuel Holly, the man with whom Acker had cohabitated for twenty-five years prior to her conviction, testified against her as part of his own plea agreement. Id. at 512. Acker's assertion of the marital privileges was based on her argument that the court should recognize their common law marriage. Id. at 514. The Fourth Circuit looked first to the laws of New York and North Carolina, the only states in which the couple resided throughout their relationship. Id. Because neither state recognized common law marriage, the court determined that Acker and Holly were not validly married. Id. at 514-15. The court denied Acker's argument that it should look to the Equal Protection Clause of the Fourteenth Amendment to extend to her common law marriage "the same 
policies of preserving marital harmony and protecting the intimate nature of marital communications are generally seen to outweigh the consequence of excluding otherwise admissible evidence from the fact finder. ${ }^{62}$ Because the confidential marital communications privilege and the spousal testimony privilege protect a public policy viewed to outweigh even a court's search for the truth, these privileges are rather significant.

\section{A. The Confidential Marital Communications Privilege}

All state and federal jurisdictions in the United States recognize the confidential marital communications privilege in some form. ${ }^{63}$ This privilege protects from disclosure intimately shared communications

rights and privileges that are extended to married individuals in federal courts." Id. at 514 . The court continued that "reason dictates that before the courts extend a marital privilege to benefit a defendant, the defendant must have assumed both the privileges and responsibilities of a valid marriage under the law of the state in which the privilege is asserted." $I d$. at 515 . Interestingly, the Fourth Circuit looked to the laws of the state in which the privilege was asserted as well as the laws of the states in which the couple had resided throughout the entirety of their relationship. Id. at 514 .

62. See, e.g., Bergstrom \& Denvil, supra note 1, at 229-31 (citations omitted) (explaining that marital harmony and confidences served as the foundation of the marital privileges); La Vita, supra note 1, at 261 (citing Wolfle v. United States, 291 U.S. 7, 14 (1934)) ("Courts have long recognized marital communications as privileged because the preservation of marriage outweighs the disadvantages imposed in excluding the evidence.").

63. Ala. R. Evid. 504; Alaska R. Evid. 505; Ariz. Rev. Stat. AnN. $\S \S 12-2231$ to -2232 (Supp. 2013); ARIZ. REv. STAT. ANN. $§ 13-4062$ (2010); ARK. R. Evid. 504; CAL. Evid. CODE $\S \S$ 970-973, 980-987 (West 2009); Colo. Rev. Stat. AnN. § 13-90-107(1)(a) (West 2014); State v. Christian, 841 A.2d 1158, 1173 (Conn. 2004); DEL. R. Evid. 504; D.C. CoDE § 14-306 (Supp. 2014); FLA. STAT. $\S 90.504$ (West 2011); GA. CODE ANN. $\S \S 24-5-501$ to 5-503 (West 2013); HAW. R. EvID. 505; IdAHo R. Evid. 504; 735 Ill. Comp. Stat. AnN. 5/8-801 (West 2003); 725 Ill. Comp. StAT. ANN. 5/115-16 (West Supp. 2014); IND. CODE ANN. § 34-46-3-1(4) (West 2011); IOWA CODE ANN. § 622.9 (West 2014); Kan. Stat. AnN. § 60-423(b) (West Supp. 2008); Kan. Stat. AnN. § 60-428 (West Supp. 2008); KY. R. EvID. 504; LA. CoDE EvID. ANN. § 504-505 (2014); ME. R. EvID. 504; Md. Code Ann. Cts. \& Jud. Proc. $\S \S 9-105$ to -106 (West 2011); MAss. Gen. LAws AnN. ch. 233, $\S 20$ (West 2000); Mich. COMP. LAWS ANN. $§ 600.2162$ (West 2010); MinN. STAT. ANN. $§ 595.02$ (West Supp. 2014); Miss. R. Evid. 504; Mo. AnN. StAT. § 546.260 (West 2002); MonT. CodE AnN. § 26-1-802 (2013); NeB. ReV. Stat. AnN. § 27-505 (West 2009); NeV. REV. Stat. AnN. § 49.295 (West 2004); N.H.R. Evid. 504; N.J. STAT. ANN. $§$ 2A:84A-17, -22 (West 2011); N.M. STAT. ANN. $\S$ 38-6-6 (West 2010); N.Y. C.P.L.R. 4502 (McKinney 2007); N.C. GEN. STAT. ANN. §§ 8-56 to -57 (West Supp. 2013); N.D.R. Evid. 504; OHIo ReV. CODE ANN. §§ 2317.02, 2945.42 (West Supp. 2014); OKLA. Stat. AnN. tit. 12, § 2504 (West 2014); Or. ReV. Stat. AnN. § 40.255 (West 2003); 42 Pa. Cons. Stat. AnN. $\S \S 5913,5915,5923-24$ (West 2013); R.I. GEN. LAws ANN. § 9-17-13 (West Supp. 2014); S.C. CoDE ANN. $§ 19-11-30$ (2014); S.D. CoDIFIED LAws $\S \S 19-13-12$ to -15 (2004); TENN. CoDE ANN. § 24-1-201 (West 2002); TeX. R. Evid. 504; UtAH R. Evid. 502; VT. StAT ANN. tit. 12, § 1605 (West 2007); VA. CoDE ANN. § 8.01-398 (West Supp. 2014); VA. CODE ANN. § 19.2-271.2 (West 2007); WASH. REV. CODE ANN. § 5.60.060 (West Supp. 2014); W. VA. Code AnN. § 57-3-4 (West 2002); Wis. Stat. AnN. § 905.05 (West Supp. 2013); Wyo. Stat. AnN. $\S 1-12-104$ (West 2007). 
between spouses. ${ }^{64}$ It "bars testimony concerning intra-spousal, confidential expressions arising from the marital relationship." ${ }^{\circ 5}$ The privilege covers only communications. ${ }^{66}$ Moreover, the communication must have been made privately. ${ }^{67}$ Essentially, it enables married couples to discuss everything from dirty laundry to pillow talk without fear that such conversations will later become public. To ensure the ongoing maintenance of such confidentiality, it may be asserted by either spouse to prevent even a willing spouse-witness from testifying adversely to the party-spouse's interests. ${ }^{68}$

The public policy behind the confidential marital communications privilege is to preserve the intimacy of marital communications. ${ }^{69}$ In Stein v. Bowman, the United States Supreme Court explained the significance of the privilege in federal common law as follows: "To break down or impair the great principles which protect the sanctities of husband and wife, would be to destroy the best solace of human existence."70 So important is this policy that the confidential marital communications privilege even survives the termination of the marriage. $^{71}$ This privilege makes certain one's ability to relieve herself from her burdens in the moment, knowing they will remain private even if the marriage later fails.

The confidential marital communications privilege can be traced back to Sexton v. Sexton, decided in 1905 by the Supreme Court of Iowa. ${ }^{72}$ The Court in Sexton described the origins and nature of the privilege as follows:

64. See Acker, 52 F.3d at 514 ("The 'marital communication privilege,' if applicable and properly raised, is with the defendant and prevents a spouse from testifying against the defendant regarding confidential communications between the spouses.").

65. Lustig, 555 F.2d at 747 (citing Blau v. United States, 340 U.S. 332, 333 (1951); United States v. Harper, 450 F.2d 1032, 1045 (5th Cir. 1971)).

66. See id. at 748 (citing Pereira v. United States, 347 U.S. 1, 6 (1953); United States v. Smith, 533 F.2d 1077, 1079 (8th Cir. 1976)) ("It is well established that the privilege applies only to utterances or expressions intended by one spouse to convey a message to the other.").

67. See id. (citing Pereira, 347 U.S. at 6-7; United States v. Burks, 470 F.2d 432, 434 (D.C. Cir. 1972)) ("Communications made to or in the presence of third parties are not intended to be confidential and are not privileged."). Marital communications, however, receive a presumption of confidentiality. Blau, 340 U.S. at 333 (citing Wolfle v. United States, 291 U.S. 7, 14 (1934)).

68. Acker, 52 F.3d at 514 .

69. See Roberts, supra note 54 (discussing the history and public policy behind the spousal immunity privilege).

70. 38 U.S. 209, 223 (1839).

71. Lustig, 555 F.2d at 747 (citing Pereira, 347 U.S. at 6; United States v. Lewis, 433 F.2d 1146, 1150 (D.C. Cir. 1970))

72. 105 N.W. 314 (Iowa 1905). 
The privilege of communications between husband and wife, was secured at common law. The rule was not designed to suppress truth, but had its origin in the fact, made clear by experience, that greater mischiefs resulted from the admission of such evidence than were likely to arise from its exclusion. In common, therefore, with other privileges, analogous in character, it was grounded on public policy. In stating the reasons for the privilege Mr. Greenleaf says: "The happiness of the married state requires that there should be the most unlimited confidence between husband and wife, and this confidence the law secures by providing that it shall be kept forever inviolable; that nothing shall be extracted from the bosom of the wife which was there confided by her husband.",73

Citing the Iowa Supreme Court's reasoning in Sexton, the Supreme Court of the United States in Wolfle v. United States stated: "The basis of the immunity given to communications between husband and wife is the protection of marital confidences, regarded as so essential to the preservation of the marriage relationship as to outweigh the disadvantages to the administration of justice which the privilege entails." 74 In Wolfle, the Supreme Court further explained that the existence of the confidential marital communications privilege should be determined on a case-by-case basis. ${ }^{75}$

All fifty states and the District of Columbia recognize the confidential marital communications privilege in some form, ${ }^{76}$ even if those states may not also recognize the spousal immunity privilege. ${ }^{77}$ Those states that recognize confidential marital communications but not spousal immunity reason that the purpose of preserving marital harmony is sufficiently served through the former; the latter being viewed as an unnecessary extension and perhaps an unnecessary obstruction to the truth. $^{78}$

When the United States Supreme Court promulgated the Federal Rules of Evidence in 1972, however, it intentionally omitted the confidential marital communications privilege traditionally recognized

73. Id. at 315 (citing 1 GREENLEAF ON EVIDENCE $§ 254$ ).

74. 291 U.S. 7, 14 (1934) (citing Sexton, 105 N.W. at 315; Hammons v. State, 84 S.W. 718, 720 (Ark. 1905); O’Toole v. Ohio Ger. Fire Ins. Co., 123 N.W. 795, 797 (Mich. 1909)).

75. See id. (distinguishing between communications that were intended to be private and communications made in the presence of a third person to determine the applicability of the privilege).

76. See supra note 63

77. See infra note 86 and accompanying text.

78. See Mikah K. Story, Twenty-First Century Pillow-Talk: Applicability of the Marital Communications Privilege to Electronic Mail, 58 S.C. L. REV. 275, 278-83 (2006) (discussing criticism concerning the communications privilege). 
under federal common law. ${ }^{79}$ The Supreme Court took the opposite view of those states that prefer the confidential marital communications privilege to the spousal testimony privilege when it suggested preserving the spousal testimony privilege in Proposed Federal Rule of Evidence 505 while rejecting the confidential marital communications privilege. ${ }^{80}$ In drafting Proposed Rule 505, the Advisory Committee on the Federal Rules of Evidence reasoned that spousal immunity is inclusive of most scenarios that would include divulgence of confidential marital communications, rendering a marital communications privilege superfluous. ${ }^{81}$ Recognizing that federal common law already maintained a confidential marital communications privilege, Congress criticized Proposed Rule 505 as a "conscious decision of the Court to narrow its [husband-wife privilege] scope from that recognized under present Federal decisions." 82 Much of the Congressional criticism was aimed at the extreme disparity between many states' privilege laws - all fifty states recognized the confidential marital communications privilege ${ }^{83}$ and the proposed rule. ${ }^{84}$ Because Proposed Rule 505 was never enacted, however, the confidential marital communications privilege persists at federal common law. ${ }^{85}$

\section{B. Spousal Testimony Privilege}

A majority of jurisdictions in the United States also recognize some form of the spousal testimony privilege, often referred to as spousal

79. See Mark Reutlinger, Policy, Privacy, and Prerogatives: A Critical Examination of the Proposed Federal Rules of Evidence as They Affect Marital Privilege. 61 CALIF. L. REV. 1353, 1369 (1973) (providing the Advisory Committee's reasoning for excluding the communications privilege).

80. See, e.g., Development in the Law-Privileged Communications, 98 HARV. L. REV. 1563, 1565 (1985) ("many state legislatures recognized the need for distinct protection of confidential marital communications"); Kimberly Ann Connor, A Critique of the Marital Privileges: An Examination of the Marital Privileges in the United States Military Through the State and Federal Approaches to the Marital Privileges, 36 VAL. U. L. REV. 119, 135-38 (2001) (asserting that the communications privilege "stemmed from the state legislatures' recognition of the need for the explicit protection of confidential martial communications").

81. See, e.g., Development in the Law, supra note 80, at 1564 (stating that the two privileges often overlap); Connor, supra note 80, at 146 (discussing how the modern federal trend is to narrow marital privileges).

82. S. REP. NO. 93-1277, at 7053 (1974).

83. See supra note 63 .

84. FED. R. EvID. 505, 51 F.R.D. 315 (proposed Mar. 1971).

85. See Reutlinger, supra note 79, at 1354 (stating that Congress decreed that the Rules would have no force). 
immunity. ${ }^{86}$ The spousal testimony privilege allows a spouse with information sought for disclosure at trial to invoke the privilege to avoid testifying adversely to his or her spouse altogether on any subject at any time for the duration of the marriage. ${ }^{87}$ This "privilege is vested in the witness-spouse, who may neither be compelled to testify nor foreclosed from testifying." 88 The spousal testimony privilege "is what remains of the old common law rule that a spouse was incompetent as a witness for or against the other spouse based on the legal fiction that husband and wife were one person." 89 As such, allowing a wife to testify against her

86. Ala. CODE § 12-21-227 (2012); Alaska R. Evid. 505(a); ARIZ. REv. STAT. ANN. § 134062 (2010); CAL. Evid. Code $§ 970$ (West 2009); Colo. Rev. STAT. AnN. § 13-90-107 (West 2014); ConN. Gen. STAT. ANN. § 54-84a (West Supp. 2014); D.C. CODE § 14-306 (Supp. 2014); GA. Code ANN. § 24-5-503 (West 2013); HAW. ReV. Stat. § 626-1, R. 505 (West 2008); IDAHo Code ANN. § 19-3002 (West 2006); KY. R. EvID. 504; LA. CodE EvID. ANN. art. 505 (Supp. 2014); MD. Code Ann., Cts. \& Jud. Proc. § 9-106 (West 2011); Mass. Gen. LaWs AnN. ch. 233, § 20 (West 2000); Мich. Comp. LaWs AnN. § 600.2162 (West 2010); MinN. Stat. ANN. § 595.02 (West Supp. 2014); Miss. Code AnN. § 13-1-5 (West 2013); Mo. AnN. STAT. § 546.260 (West 2002); Neb. ReV. Stat. AnN. § 27-505 (West 2009); NEV. ReV. StAT. ANN. § 49.295 (West 2004); N.J. Stat. ANN. § 2A:84A-17(2) (West 2011); N.C. Gen. Stat. AnN. § 8-57 (West Supp. 2013); Ohio Rev. Code ANN. $\$ 2945.42$ (West 2006); OR. Rev. STAt. ANN. $\$ 40.255$ (West 2003); 42 PA. CONS. STAT. ANN. $\S 5913$ (West 2013); R.I. GEN. LAWS ANN. § 12-17-10 (West 2006); TEX. R. EVID. 504(b); UTAH CODE ANN. § 78B-1-137 (West 2009); VA. CODE ANN. § 19.2-271.2 (West 2007); WASH. REV. CodE ANN. § 5.60.060(1) (West Supp. 2014); W. VA. CODE ANN. § 57-3-3 (West 2002); Wyo. STAT. ANN. $\S 1-12-104$ (West 2007).

87. See Roberts, supra note 54 , at 1.

88. United States v. Acker, 52 F.3d 509, 514 (4th Cir. 1995) (citing Trammel v. United States, 445 U.S. 40, 53 (1980)). See also, e.g., Trammel, 445 U.S. at 53 (1980) (modifying the Hawkins rule "so that the witness-spouse alone has a privilege to refuse to testify adversely; the witness may be neither compelled to testify nor foreclosed from testifying"); United States v. Lustig, 555 F.2d 737, 747 (9th Cir. 1977) ("[the spousal testimony] privilege permits either spouse, upon objection, to exclude adverse testimony by the other").

89. Lustig, 555 F.2d at 747 (citing Hawkins v. United States, 358 U.S. 74, 75-76 (1958); Bisno v. United States, 299 F.2d 711, 721 (9th Cir. 1961), cert. denied, 370 U.S. 952 (1962)). See also Trammel, 445 U.S. at 44 (discussing the origins of marital privilege). In Lustig, the Ninth Circuit heard the appeal of defendant George Lustig from his conviction on various federal drug charges. 555 F.2d at 742. He challenged the refusal of the District of Alaska to recognize either the spousal testimony privilege or the confidential marital communications privilege to prevent his common law wife of seven years, Callie Newton, from testifying. Id. at 747. The court looked to the law of the State of Alaska to determine the validity of their marriage; Alaska was both the state of their shared residence and the state in which the privilege was asserted. Id at 747-48. The Ninth Circuit assumed the existence of a common law marriage because the pair lived together for seven years, had two children, and held themselves out as husband and wife. Id. at 747 n. 11 . Because Alaska did not recognize common law marriage, however, the Ninth Circuit affirmed the ruling of the district court. Id. at 748. The Ninth Circuit declined to address whether the district court was compelled by the Equal Protection Clause of the Fourteenth Amendment to recognize the common law marriage, noting that neither privilege would apply if recognized; the spousal testimony privilege would not apply because the relationship ended prior to Newton's testimony and the confidential marital communications privilege did not apply because "Newton's testimony concerned matters neither communicative nor confidential in nature." Id. 
husband was tantamount to self-incrimination. ${ }^{90}$ Fortunately, that explanation has evolved.

The public policy sustaining the privilege today is the maintenance of marital harmony. ${ }^{91}$ It is quite obvious that forcing an unwilling witness to testify adversely to his or her spouse in an otherwise healthy marriage could irreparably damage that relationship. The spousal testimony privilege prevents such forced testimony from an unwilling spouse, but does not prevent a willing spouse from testifying - in which case, "their relationship is almost certainly in disrepair; there is probably little in the way of marital harmony for the privilege to preserve." 92

Thirty-one states and the District of Columbia recognize a testimonial privilege for spouses. ${ }^{93}$ Of those, fifteen include language specific to heterosexual couples, ${ }^{94}$ while sixteen use gender neutral language that could be easily applied to same-sex couples if those jurisdictions recognized marriage equality. ${ }^{95}$ Federal common law on the spousal testimony privilege limits its application to criminal cases. ${ }^{96}$ Thus, the spousal testimony privilege is more limited in its application than the confidential marital communications privilege.

90. See, e.g., Lustig, 555 F.2d at 747 (citing Hawkins, 358 U.S. at 75-76) (stating that the privilege comes from the legal fiction of husband and wife being one person); Trammel, 445 U.S. at 43-44 (same).

91. See Trammel, 445 U.S. at 52 (explaining that the contemporary justification for the privilege is marital harmony).

92. Id.

93. See supra note 86

94. Ala. CODE § 12-21-227 (2012); Alaska R. Evid. 505(a); ARIz. Rev. Stat. AnN. § 134062 (2010); Colo. Rev. STAT. ANN. § 13-90-107 (West 2014); GA. CODE ANN. § 24-5-503 (West 2013); IdAHO COdE ANN. § 19-3002 (West 2006); MASs. Gen. LAwS ANN. ch. 233, § 20 (West 2000); Мich. Comp. Laws AnN. § 600.2162 (West 2010); MinN. Stat. ANN. § 595.02 (West Supp. 2014); Neb. Rev. Stat. ANN. § 27-505 (West 2009); NeV. Rev. STAT. ANN. § 49.295 (West 2004); OR. ReV. Stat. ANN. § 40.255 (West 2003); VA. CODE ANN. § 19.2-271.2 (West 2007); W. VA. CODE ANN. § 57-3-3 (West 2002); Wyo. STAT. ANN. § 1-12-104 (West 2007).

95. Cal. Evid. Code $\S 970$ (West 2009); Conn. Gen. Stat. AnN. § 54-84a (West Supp. 2014); D.C. Code $§ 14-306$ (Supp. 2014); HAW. REV. Stat. § 626-1, R. 505 (West 2008); KY. R. Evid. 504; La. Code Evid. ANN. art. 505 (Supp. 2014); MD. Code ANN., CTS. \& JuD. Proc. § 9-106 (West 2011); Miss. Code ANN. \$13-1-5 (West 2013); Mo. ANN. STAT. § 546.260 (West 2002); N.J. StAT. ANN. § 2A:84A-17(2) (West 2011); N.C. GEN. STAT. ANN. § 8-57 (West Supp. 2013); OHIO R. EVID. 601; 42 PA. CONS. STAT. ANN. § 5913 (West 2013); R.I. GeN. LAWS ANN. § 12-17-10 (West 2006); TeX. R. Evid. 504(b); UtAH Code ANN. § 78B-1-137 (West 2009); WASH. Rev. Code ANN. $\S 5.60 .060(1)$ (West Supp. 2014).

96. United States v. 281 Syosset Woodbury Rd., 71 F.3d 1067, 1070 (2d Cir. 1995). 


\section{FRE 501}

The Federal Rules of Evidence are soft-spoken on all privileges, including marital privileges, to say the least. When the United States Supreme Court promulgated the Federal Rules of Evidence in 1972, it expressly included the spousal testimony privilege, among others. ${ }^{97}$ Because the promulgated rules omitted a number of other privileges, including the confidential marital communications privilege and the physician-patient privilege, Congress balked at the proposed rules governing privileges. ${ }^{98}$ Questions were raised as to why the spousal testimony privilege was preferred over the confidential marital communications privilege. $^{99}$ After years of Congressional Hearings and debate on the broader issue of privilege, Congress rejected a codification of specific privileges, instead favoring a broad provision placing discretion on the common law to continue the evolutionary development of testimonial privileges. ${ }^{100}$

There is no codified federal marital privilege. Instead, under the Federal Rules, a federal court applying a marital privilege must first look to Federal Rule of Evidence 501. Rule 501 instructs federal courts to apply the privilege laws of the state supplying the rules of decision in a diversity case, or to apply the federal common law on privileges in a case in which federal substantive law applies. ${ }^{101}$ Its purpose is to "provide the courts with the flexibility to develop rules of privilege on a case-by-case basis." 102

In sum, all fifty states, the District of Columbia, and federal common law recognize the confidential marital communications privilege, ${ }^{103}$ while a majority of states, the District of Columbia, and federal common law also recognize the spousal testimony privilege. ${ }^{104}$ What these

\footnotetext{
97. Connor, supra note 80 , at $136 \&$ n. 75 .

98. Roberts, supra note 54, at 3.

99. See id.

100. See Trammel v. United States, 445 U.S. 40, 47 (1980) ("[t]he Federal Rules of Evidence acknowledge the authority of the federal courts to continue the evolutionary development of testimonial privileges in federal criminal trials").

101. FED. R. EvID. 501.

102. Trammel, 445 U.S. at 47 (quoting 120 CONG. REC. 40891 (1974) (statement of Rep. Hungate)).

103. See supra note 63

104. See supra note 86 .
} 
privileges do not answer is whether a court should apply them to samesex spouses. ${ }^{105}$

\section{MARITAL PRIVILEGES UNDER FEDERAL LAW IN THE ABSENCE OF DOMA $\S 3$}

A valid marriage is key to a court's decision to apply a marital privilege. ${ }^{106}$ However, states are greatly divided at the moment over what constitutes a valid marriage. ${ }^{107}$ On June 26, 2013, the United States Supreme Court issued its opinion in United States $v$. Windsor, striking $\S$ 3 of DOMA - which defined marriage as between a man and a womanas unconstitutional. ${ }^{108}$ Nonetheless, current federal law protects a state's right to treat as invalid a same-sex marriage validly celebrated and recognized in another state. ${ }^{109}$ Many states retain statutory bans on same-sex marriage as well as constitutional prohibitions; ${ }^{110}$ in many jurisdictions, these provisions also prevent recognition by the state of same-sex marriages validly obtained elsewhere. ${ }^{111}$ Same-sex couples today straddle vastly opposite laws governing the validity of their marriages across state lines. Those competing definitions of a valid marriage could prevent same-sex couples from exercising the full benefits of their marital privileges. ${ }^{112}$

\section{A. The History of DOMA and Mini-DOMAs}

To understand the purposes behind the federal DOMA and its state counterparts - as is required for any constitutional analysis concerning these laws - one must become familiar with the progression of same-sex marriage laws prior to 1996. In the early 1970s, plaintiffs brought a few constitutional challenges demanding that state officials issue marriage licenses to same-sex couples. ${ }^{113}$ In each case, the court ruled that a

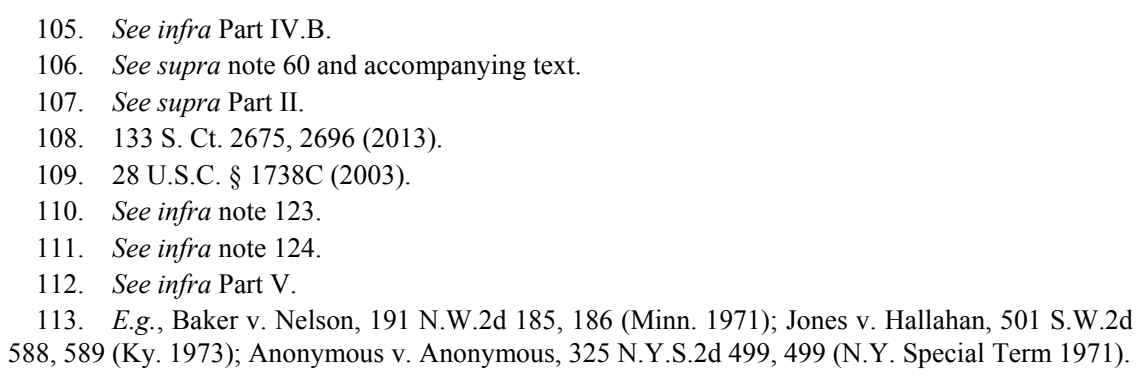


same-sex relationship was not a marriage. ${ }^{114}$ Over two decades later, this jurisprudence was shaken when the Supreme Court of Hawaii ruled in Baehr v. Lewin that the state's prohibition on same-sex marriage violated the protections of the Hawaii Constitution, specifically its equal protection clause. ${ }^{115}$

In response to Baehr, the United States Congress enacted DOMA and many states enacted similar mini-DOMAs to "defend the institution of traditional heterosexual marriage" from expansion to include same-sex partnerships. ${ }^{116}$ DOMA contains two key provisions. In $\S 2$, DOMA states that:

No State, territory, or possession of the United States, or Indian tribe, shall be required to give effect to any public act, record, or judicial proceeding of any other State, territory, possession, or tribe respecting a relationship between persons of the same sex that is treated as a

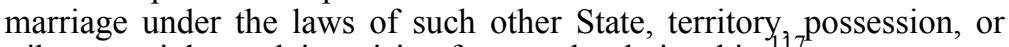
tribe, or a right or claim arising from such relationship.

Section 3 provides:

In determining the meaning of any Act of Congress, or of any ruling, regulation, or interpretation of the various administrative bureaus and agencies of the United States, the word "marriage" means only a legal union between one man and one woman as husband and wife, and the word "spouse" refers only to a person of the opposite sex who is a husband or a wife. ${ }^{118}$

Three years after DOMA was enacted, the Supreme Court of Vermont required the State to provide all the benefits of marriage to same-sex couples in Baker v. Vermont. ${ }^{119}$ In 2003, the Supreme Judicial Court of Massachusetts decided Goodridge v. Dep't of Pub. Health, striking its statutory ban on same-sex marriage as violative of its state constitution. $^{120}$ In response to those decisions, many states amended their own constitutions to include same-sex marriage bans, thus ensuring

\footnotetext{
501.

114. E.g., Baker, 191 N.W.2d at 187; Jones, 501 S.W.2d at 590; Anonymous, 325 N.Y.S.2d at

115. 852 P.2d 44, 67 (Haw. 1993).

116. United States v. Windsor, 133 S. Ct. 2675, 2693 (2013) (quoting H.R. REP. No. 104-664, at 2, $12(1996))$.

117. 28 U.S.C. $\$ 1738 \mathrm{C}(2012)$.

118. 1 U.S.C. $\$ 7$ (2013), invalidated by Windsor, 133 S. Ct. 2675.

119. 744 A.2d 864, 886-87 (Vt. 1999).

120. 798 N.E.2d 941, 969 (Mass. 2003).
} 
that their mini-DOMA statutes did not run afoul of their state constitutions. $^{121}$

Although many states have now extended some form of legal rights to same-sex couples, ${ }^{122}$ forty-two states have or have had statutes or constitutional amendments limiting marriage to a union of a man and a woman. $^{123}$ Twenty of those states prohibit or have prohibited legal

121. See, e.g., Bourke v. Beshear, 996 F. Supp. 2d 542, 544-45 (W.D. Ky. 2014) (internal citations omitted) ("The reaction was immediate and visceral. In the next few years, twenty-seven states passed anti-same-sex marriage legislation, and Congress passed the Defense of Marriage Act (DOMA). In 1998, Kentucky became one of those states, enacting new statutory provisions that (1) defined marriage as between one man and one woman, K.R.S. § 402.005; (2) prohibited marriage between members of the same sex, K.R.S. $§ 402.020(1)(d)$; (3) declared same-sex marriages contrary to Kentucky public policy, K.R.S. $\S 402.040(2)$; and (4) declared same-sex marriages solemnized out of state void and the accompanying rights unenforceable, K.R.S. § 402.045.3.”).

122. See supra notes $43-47$ and accompanying text.

123. Ala. Const. art. I, § 36.03; Alaska Const. art. I, § 25; Alaska Stat. AnN. §§ 25.05.011, .013 (West 2007); ARIZ. CONST. art. XXX, § 1; ARIZ. REV. STAT. ANN. \$§ 25-101, $25-$ 112 (West 2007); ARK. CONST. amend. 83, invalidated by Wright v. Arkansas, No. 60CV-13-2662, 2014 WL 1908815 (Ark. Cir. Ct. May 9, 2014) (stayed pending appeal to the Eighth Circuit); ARK. CODE ANN. § 9-11-109 (West 2009), invalidated by Wright, 2014 WL 1908815 (same); CAL. FAM. CODE $\S 308.5$ (West 2004), invalidated by Perry v. Brown, 671 F.3d 1052 (9th Cir. 2013), vacated and remanded, Hollingsworth v. Perry, 133 S. Ct. 2652 (U.S. 2013) (instructing Ninth Circuit to "dismiss the appeal for lack of jurisdiction"); COLO. CONST. art. II, § 31, invalidated by Brinkman v. Long, No. 13-CV-32572, 2014 WL 3408024 (D. Colo. July 9, 2014) (stayed by the Colorado Supreme Court pending appeal to be heard later this year); Colo. REv. STAT. ANN. § 14-2-104 (West Supp. 2013), invalidated by Brinkman, 2014 WL 3408024 (same); DEL. CODE. ANN. tit. 13, § 101 (1999) (amended 2013); FLA. CONST. art. I, § 27, invalidated by Brenner v. Scott, Nos. 4:14cv107-RH/CAS, 4:14cv138-RH/CAS, 2014 WL 4113100 (N.D. Fla. Aug. 21, 2014) (stayed pending appeal to the Tenth Circuit); FLA. STAT. ANN. §§ 741.04(1), .212 (West 2010), invalidated by Brenner, 2014 WL 4113100 (same); GA. CONST. art. I, § 4, para. 1; GA. CODE ANN. § 19-3-3.1 (West 2010); HaW. ReV. Stat. § 572-1 (West 2003) (amended 2013), HAW. REV. STAT. § 572-1.6 (West 2003) (repealed 2011); IDAHO CONST. art. III, § 28, invalidated by Latta v. Otter, No. 1:13-cv00482-CWD, 2014 WL 1909999 (D. Idaho May 13, 2014) (stayed pending appeal to the Ninth Circuit); IDAHO CODE ANN. § 32-209 (West 2013), invalidated by Latta, 2014 WL 1909999 (same); 750 ILL. COMP. STAT. ANN. §§ 5/212, /213.1 (West 1999) (repealed 2013); IND. CODE ANN. § 31-111-1 (West 2008), invalidated by Baskin v. Bogan, Nos. 14-2386, 14-2387, 14-2388, 14-2526, 2014 WL 4359059 (7th Cir. Sept. 4, 2014) (pending appeal to the United States Supreme Court); KAN. CONST. art. XV, § 16; KAN. STAT. ANN. § 23-2501 (Supp. 2013); KY. CONST. § 233A, invalidated by Love v. Beshear, 989 F. Supp. 2d 536 (W.D. Ky. 2014) (stayed pending appeal to the Sixth Circuit); KY. REV. STAT. ANN. $\S \S 402.005, .020, .040, .045$ (West 2006), invalidated by Love, 989 F. Supp. 2d 536 (same); LA. Const. art. XII, § 15; LA. Civ. Code ANN. arts. 89, 96 (West 2013); LA. Civ. Code AnN. art. 3520 (West 2011); Me. Rev. Stat. tit. 19-A, § 650 (1998) (repealed 2012); MD. CODE ANN., FAM. LAW § 2-201 (1999) (repealed 2012); MicH. CONST. art. I, § 25, invalidated by DeBoer v. Snyder, 973 F. Supp. 2d 757 (E.D. Mich. 2014) (stayed pending appeal to the Sixth Circuit); Mich. COMP. LAWS ANN. $\S \S 551.1, .271, .272$ (West 2005), invalidated by DeBoer, 973 F. Supp. 2d 757 (same); MinN. STAT. § 363A.27 (2004) (amended 2013), MinN. STAT. ANN. § 517.01 (2005) (amended 2013); Miss. Const. art. XIV, § 263A; Miss. CodE ANN. § 93-1-1(2) (West 2007); Mo. CONST. art. I, § 33; Mo. AnN. STAT. § 451.022 (West 2003); MonT. Const. art. XIII, § 7; Mont. Code ANN. $\S \S 40-1-103,-401$ (2013); NeB. CONST. art. I, § 29; NEv. Const. art. I, § 21; N.C. CONST. art. XIV, § 6; N.C. GEN. STAT. ANN. §§ 51-1, -1.2 (West 2013); N.D. CONST. art. XI, § 28; N.D. CENT. CODE ANN. §§ 14-03-01, -08 (West 2008); OHIO CONST. art. XV, § 11, invalidated 
recognition of a legal same-sex marriage celebrated in another jurisdiction. ${ }^{124}$ Because such statutes or constitutional amendments are modeled after DOMA, they are referred to as mini-DOMAs. ${ }^{125}$

in part by Henry v. Himes, No. 1:14-cv-129, 2014 WL 1418395 (S.D. Ohio Apr. 14, 2014) (stayed pending appeal to the Sixth Circuit); OHIO REV. CODE ANN. § 3101.01 (West 2011), invalidated in part by Henry, 2014 WL 1418395 (same); OKLA. CONST. art. II, § 35, invalidated by Bishop v. United States ex rel. Holder, 962 F. Supp. 2d 1252 (N.D. Okla. 2014), aff'd, Bishop v. Smith, Nos. 14-5003 \& 14-5006, 2014 WL 3537847 (10th Cir. July 18, 2014) (stayed pending petition for certiorari); OKLA. STAT. ANN. tit. 43, $\S \S 3,3.1$ (West 2001), invalidated by Bishop, 962 F. Supp. 2d 1252 (same); OR. CONST. art. XV, § 5a, invalidated by Geiger v. Kitzhaber, 994 F. Supp. 1128 (D. Or. 2014); 23 Pa. Cons. STAT. § 1704 (2001), invalidated by Whitewood v. Wolf, 992 F. Supp. 410 (M.D. Pa. 2014); S.C. Const. art. XVII, § 15; S.C. CoDE ANN. §§ 20-1-10, -15 (2014); S.D. ConsT. art. XXI, $\S 9$; S.D. CodIFIED LAws $\S \S 25-1-1$, -38 (2013); TENN. ConsT. art. XI, $\S 18$, called into question by Tanco v. Haslam, No. 3:13-cv-01159, 2014 WL 997525 (M.D. Tenn. Mar. 14, 2014) (granting preliminary injunction enjoining officials from enforcing same-sex marriage ban; pending appeal to the Sixth Circuit); TENN. CODE ANN. § 36-3-113 (West 2009), called into question by Tanco, 2014 WL 997525 (same); TEX. ConsT. art. I, § 32, invalidated by De Leon v. Perry, 975 F. Supp. 2d 632 (W.D. Tex. 2014) (stayed pending appeal to the Fifth Circuit); TEX. FAM. CODE ANN. $\S \S 2.001,6.204$ (West 2009), invalidated by De Leon, 975 F. Supp. 2d 632 (same); UTAH CONST. art. I, § 29, invalidated by Kitchen v. Herbert, 755 F.3d 1193, 1229-30 (10th Cir. 2014) (stayed pending petition for certiorari); UTAH CODE ANN. $\S \S 30-1-2,30-1-4.1$ (West 2004), invalidated by Kitchen, 755 F.3d 1193 (same); VA. ConsT. art. I, § 15-A, invalidated by Bostic v. Schaefer, Nos. 14-1167, 14-1169, 14-1173, 2014 WL 3702493 (4th Cir. July 28, 2014) (stayed pending petition for certiorari); VA. CODE ANN. § 20-45.2, -45.3 (West Supp. 2014), invalidated by Bostic v. Schaefer, Nos. 14-1167, 14-1169, 14-1173, 2014 WL 3702493 (4th Cir. July 28, 2014) (stayed pending petition for certiorari); VT. STAT. ANN. tit. 15, § 8 (2002) (amended 2009); WASH. REV. CODE $\S$ 26.04.010, .020 (West Supp. 2005) (amended 2012); W. VA. CoDE ANN. § 48-2-104 (West Supp. 2013); W. VA. CODE ANN. § 48-2-603 (West 2002); WIS. CONST. art. XIII, § 13, invalidated by Wolf v. Walker, No. 14-cv-64-bbc, 2014 WL 2693963 (W.D. Wis. June 13, 2014), aff'd, Baskin, 2014 WL 4359059 (stayed pending appeal to the United States Supreme Court); WYO. STAT. ANN. § 201-101 (West 2014).

124. Ala. Const. art. I, § 36.03; Alaska Stat. AnN. § 25.05.013 (West 2007); ArK. CONST. amend. 83, invalidated by Wright, 2014 WL 1908815 (stayed pending appeal to the Eighth Circuit); ARK. CODE ANN. § 9-11-109 (West 2009), invalidated by Wright, 2014 WL 1908815 (same); FLA. CONST. art. I $§ 27$, invalidated by Brenner, 2014 WL 4113100 (pending appeal to the Tenth Circuit); GA. CONST. art. I, § 4, para. 4; IDAHO CONST. art. III, § 28, invalidated by Latta, 2014 WL 1909999 (stayed pending appeal to the Ninth Circuit); KAN. CONST. art. XV, § 16; KY. CONST. § 233A, invalidated by Love, 989 F. Supp. 2d 536 (stayed pending appeal to the Sixth Circuit); LA. CONST. art. XII, § 15; MiCH. Const. art. I, § 25, invalidated by DeBoer, 973 F. Supp. 2d 757 (stayed pending appeal to the Sixth Circuit); MonT. CODE ANN. § 40-1-401 (2013); NeB. Const. art. I, $\S$ 29; N.D. CONST. art. XI, § 28; OHIO CONST. art. XV, § 11, invalidated in part by Henry, 2014 WL 1418395 (stayed pending appeal to the Sixth Circuit); S.C. ConsT. art. XVII, § 15; S.D. ConsT. art. XXI, § 9; TeX. ConsT. art. I, § 32, invalidated by De Leon v. Perry, 975 F. Supp. 2d 632, 666 (W.D. Tex. 2014) (granting stay pending appeal); UTAH CONST. art. I, § 29, invalidated by Kitchen, 755 F.3d 1193 (10th Cir. 2014) (stayed pending petition for certiorari); VA. ConST. art. I, § 15-A, invalidated by Bostic, 2014 WL 3702493 (4th Cir. July 28, 2014) (stayed pending petition for certiorari); W. VA. CODE ANN. § 48-2-603 (West 2002).

125. See supra Part IV.A. 


\section{B. The Effect of United States v. Windsor on Federal Rule of Evidence 501}

Since the Supreme Court decided United States v. Windsor ${ }^{126}$ last year, no federal court has yet had the opportunity to consider the applicability of a marital privilege to a same-sex couple absent DOMA's limited definition of marriage to opposite-sex spouses. Arguably, the issue, although different, is no easier for a federal court post-Windsor than it was under the definitional confines of DOMA's $\S 3$.

In Windsor, the Supreme Court ruled $\S 3$ of DOMA unconstitutional. ${ }^{127}$ In that case, Edith Windsor and Thea Spyer traveled from their joint home of many decades in New York to Canada to legally wed before returning to their home in New York. ${ }^{128}$ Although New York did not recognize same-sex marriage at the time, it did recognize the validity of same-sex marriages obtained legally elsewhere and afforded such relationships all the privileges and rights of a marriage in New York. ${ }^{129}$ After Spyer's death, the IRS denied the request of Windsor, as executor of her estate, to exempt the estate from estate taxes because it passed to Spyer's spouse. ${ }^{130}$

Windsor sued the United States in federal court and the United States District Court for the Southern District of New York considered this federal question. ${ }^{131}$ Both the district court and the Second Circuit held $\S$ 3 of DOMA unconstitutional and ordered the IRS to refund the taxes paid by Spyer's estate. ${ }^{132}$ The Supreme Court affirmed, striking $\S 3$ as violative of both the Due Process and Equal Protection Clauses of the Fifth Amendment. ${ }^{133}$

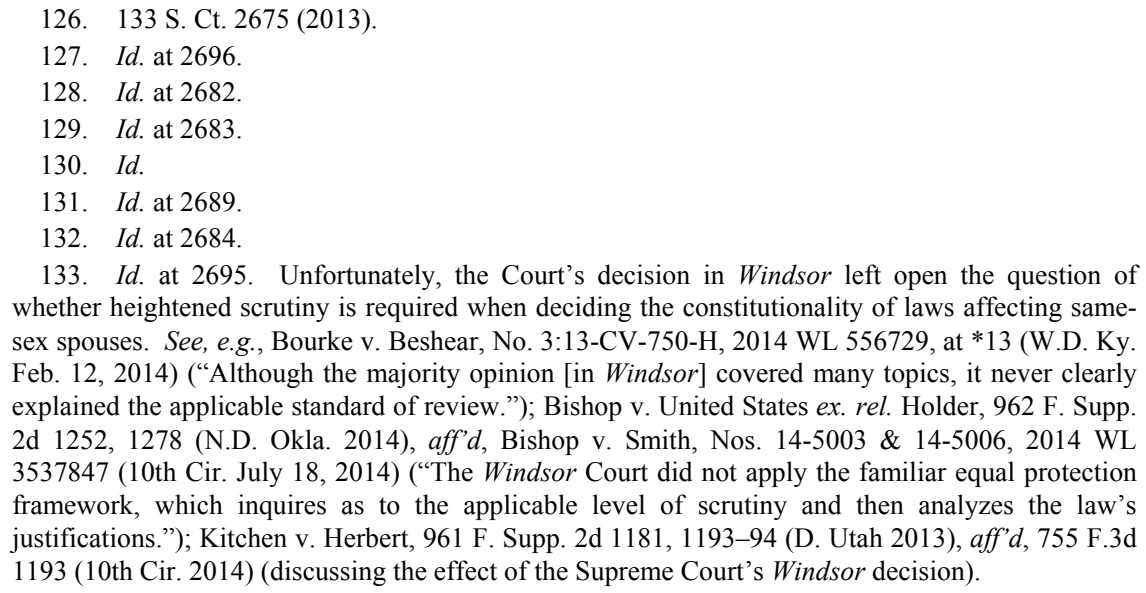

133. Id. at 2695. Unfortunately, the Court's decision in Windsor left open the question of whether heightened scrutiny is required when deciding the constitutionality of laws affecting samesex spouses. See, e.g., Bourke v. Beshear, No. 3:13-CV-750-H, 2014 WL 556729, at *13 (W.D. Ky. Feb. 12, 2014) ("Although the majority opinion [in Windsor] covered many topics, it never clearly explained the applicable standard of review."); Bishop v. United States ex. rel. Holder, 962 F. Supp. 2d 1252, 1278 (N.D. Okla. 2014), aff'd, Bishop v. Smith, Nos. 14-5003 \& 14-5006, 2014 WL 3537847 (10th Cir. July 18, 2014) ("The Windsor Court did not apply the familiar equal protection framework, which inquires as to the applicable level of scrutiny and then analyzes the law's justifications."); Kitchen v. Herbert, 961 F. Supp. 2d 1181, 1193-94 (D. Utah 2013), aff'd, 755 F.3d 1193 (10th Cir. 2014) (discussing the effect of the Supreme Court's Windsor decision). 
The definitional provision of DOMA- $\S 3$-applied to well over 1,000 Acts of Congress and countless other administrative rulings, regulations, and findings. ${ }^{134}$ The Federal Rules of Evidence, particularly Rule 501 governing privileges, were enacted by Congress in $1975 .^{135}$ They appear after Title 28 in the United States Code and are clearly "Acts of Congress" subject to $\S 3$ of DOMA. Although neither the term "marriage" nor "spouse" appears in the text of Rule 501, ${ }^{136}$ DOMA would have had a significant role in its application prior to Windsor.

To determine the applicability of a marital privilege in federal court before or after Windsor, a federal district court would first have to determine whether the jurisdiction recognizes the claimed privilege. This analysis differs depending on whether state or federal law provides the rule of decision in the case. ${ }^{137}$ Rule 501 explicitly directs federal courts sitting in diversity to apply state law to determine if a marital or other privilege applies. ${ }^{138}$ In a federal question case, however, federal courts look to federal common law to determine if a privilege applies. ${ }^{139}$

Once a federal court has determined that a privilege exists under either an applicable state law or federal common law, it must determine that there exists or existed a valid marriage on which a marital privilege can rest. ${ }^{140}$ The law of marriage is reserved to the states; ${ }^{141}$ thus, "there is

134. See Letter from Danya K. Shaw, Associate General Counsel, to the U.S. Gov't Accountability Office, available at http://www.gao.gov/new.items/d04353r.pdf (citation omitted) ("In 1997, we issued a report identifying 1,049 federal statutory provisions classified to the United States Code in which benefits, rights, and privileges are contingent on marital status or in which marital status is a factor.").

135. An Act to Establish Rules of Evidence for Certain Courts and Proceedings, Pub. L. No. 93595, 88 Stat. 1926 (1975) (codified as FED. R. EvID., 28 U.S.C.A.)

136. FED. R. EVID. 501.

137. Id.

138. Id.

139. See United States v. Knox, 124 F.3d 1360, 1365 (10th Cir. 1997). In United States v. Knox, the Tenth Circuit concluded that the confidential marital communications privilege did not apply to prevent the testimony of Robyn Cartwright, the ex-wife of defendant Michael Knox. Id. Ms. Cartwright testified that she and the defendant had divorced in September 1991, prior to the October 17, 1991 incident leading to his arrest. Id. The defendant provided no evidence that any communications relayed by Ms. Cartwright occurred prior to October 17. Id. After explaining that federal courts must look to state law to determine the existence of a marital privilege in federal court, however, the Tenth Circuit summarily decided that the privilege did not apply in this case, without citing any state law on the subject. Id. The choice of law issue of which state's law to apply was ignored. Id. Federal common law recognizes both the spousal testimony privilege and the confidential marital communications privilege. See Bergstrom \& Denvil, supra note 1, at 229-30 (internal citations omitted) ("Common law provides for both federal spousal privileges and shows that the two privileges share the similar purpose of protecting marriages.").

140. See supra note 60 and accompanying text.

141. Trammel v. United States, 445 U.S. 40, 50 (1980) (citing Sosna v. Iowa, 419 U.S. 393, 404 
no federal law of marriage."142 Because state rather than federal law governs marriages, a state law analysis of the validity of a marriage is required under any circumstance.

Under DOMA $\S 3$, before Windsor was decided, a federal court considering the validity of a marriage under the laws of a state that recognizes same-sex marriage, whether celebrated within the state or elsewhere, would have been faced with the additional challenge of determining if the definitional language of DOMA prevented the court from applying the state law in contravention of DOMA. Although no federal court ever faced this issue, it is conceivable that it would have taken one of two approaches. On one hand, a federal court could have determined that $\S 3$ of DOMA prevented it from applying the state law definition of a valid marriage where that marriage was between members of the same gender. Alternatively, a federal court considering this question under DOMA $\S 3$ could have reasoned that, because the terms "marriage" and "spouse" are not used in the Act of Congress itself (Rule 501), but in a state law defining a valid marriage, the court would not have been bound to apply the definitions of DOMA and could recognize a marital privilege between same-sex spouses. ${ }^{143}$

For example, although Edith Windsor never asserted the confidential marital communications privilege in her federal question case, ${ }^{144}$ had she attempted to, the district court would have had to look to state law to determine if Windsor and Spyer's marriage was valid. Assume for the sake of argument that New York State law was the only option on which the district court could rely. A New York court would have recognized the validity of the marriage obtained lawfully in Canada. ${ }^{145}$ A district court looking to New York law would reach the same conclusion-until it ran into DOMA. Would the district court be required to apply DOMA

(1975)).

142. Knox, 124 F.3d at 1365 (citing Trammel, 445 U.S. at 50).

143. See John Bergstresser, Note, When Evidentiary Rules Enforce Substantive Policies: SameSex Marital Privilege Under Federal Rule of Evidence 501 in Diversity Cases, 46 NEw ENG. L. Rev. 303, 313 (2012) (quoting H.R. REP. NO. 104-644, at 31, 18 (1996)) ("Under DOMA, the question of whether 'benefits available to married couples under state law will be available to homosexual couples is purely a matter of state law ... [DOMA] in no way affects that question.' Rather than usurping a state's authority to determine whether to provide state marital benefits to same-sex couples, DOMA was intended to restrict the availability of federal marital benefits only to heterosexual couples.").

144. Because the marriage had ended, Windsor could not have asserted the spousal testimony privilege in this hypothetical. See supra text accompanying note 87 . See also Roberts, supra note 54 , at 1 .

145. United States v. Windsor, 133 S. Ct. 2675, 2683 (2013). 
$\S 3$ to invalidate the marriage for privilege purposes in federal court or would the court find DOMA inapplicable to the New York State definition of "marriage" or "spouse"? No federal court ever faced that question during the 17-year tenure of DOMA $\S 3$.

Fortunately, post-Windsor, no court will ever have to answer that question because there no longer exists any federal definition of marriage in conflict with any state's definition of marriage. A valid marriage under current law will always be subject to a state law definition of marriage. Determining which state's law to apply, however, complicates matters tremendously.

\section{Choice of Law}

Determining which state's law to apply to determine the validity of a marriage even after Windsor is a complex question, whether the federal court is addressing a federal question or sitting in diversity. Not since the anti-miscegenation laws struck down in Loving $v$. Virginia ${ }^{146}$ has there been a greater divide among states over what constitutes a valid marriage. ${ }^{147}$ This opens the possibility of a federal court having to choose between the laws of a state that recognizes same-sex marriage and a state that affirmatively refuses to recognize such relationships in determining whether to recognize a marital privilege.

For example, imagine the case of a same-sex couple married and residing in New York who, two years later, travels through Texas, which maintains a mini-DOMA. While in Texas, the couple is involved in a car accident with a Texas citizen. In a Texas federal court, one spouse- the driver-is sued for damages related to the car accident. At trial, the plaintiff wishes to call the defendant's spouse to question him about communications the defendant spouse made to him in confidence in New York after they had returned from their travels. The defendant asserts the confidential marital communications privilege. The Texas district court must determine whether to recognize such a privilege. To do so, it must apply state law-but which one?

Choice of law issues could arise at two points in the analysis of whether a marital privilege will apply. This first area of conflict exists where two different states interested in the same case have conflicting laws as to the existence of a privilege; for example, if one state

146. 388 U.S. 1 (1967).

147. See supra notes $43-47$ and accompanying text, $123-24$ and accompanying text. 
recognized the confidential marital communications privilege, but another did not. ${ }^{148}$ Professor Bergstrom explains that

When two states are interested in a case but do not recognize the same privilege, generally no privilege is recognized, and the evidence is admissible. Under this approach, evidence tends to be admitted because one state's recognition of a privilege, even if that state's substantive laws apply to the case, is not sufficient to exclude the evidence. $^{149}$

In the hypothetical situation above, this conflict will not arise if both states recognize the confidential marital communications privilege.

The second choice of law issue arises when determining if a party or witness is a spouse "if the putative spouse married in another jurisdiction and the marriage is not recognized in the state in which the case is heard. The court must determine which laws govern the validity of the marriage and whether the marriage is valid." "150 As to this issue, a conflict between state laws over whether a valid marriage exists may arise even after the question of whether a privilege could exist is answered. "[A] party's home-state laws determine whether the party is a spouse. A forum state may recognize a marriage contracted in another jurisdiction even if it could not have been contracted in the forum state. Conversely, the forum state's laws may proscribe such recognition." ${ }^{\prime 51}$ Because DOMA $\S 2$

148. See Bergstrom \& Denvil, supra note 1, at 237.

149. Id. at 238 (citing Restatement (Second) OF Conflicts of Laws $§ 139$ \& cmt. d (1971)). Courts recognize an exception to this general rule where the state with the most significant relationship with the communication recognizes a marital privilege that the forum state does not and the party asserting the privilege demonstrates a "special reason why the forum policy favoring admission should not be given effect." Id. at 238-39 (quoting RESTATEMENT (SECOND) OF CONFLICTS OF LAWS § 139(2). A trial court should weigh four factors to determine if "special reasons" exist: "(1) the number and nature of the contacts that the state of the forum has with the parties and with the transaction involved, (2) the relative materiality of the evidence that is sought to be excluded, (3) the kind of privilege involved and (4) fairness to the parties." Id. at 239 (quoting Restatement (SECOND) OF CONFLICTS OF LAWS $\S 139(2) \mathrm{cmt}$. d. Courts recognize an additional exception to the general rule admitting evidence in light of a conflict of laws concerning the recognition of a marital privilege: "when admitting the evidence would be "contrary to the strong public policy of the forum." I I . at 239 (quoting RESTATEMENT (SECOND) OF CONFLICTS OF LAWS $\S$ 139(1). Given the strong debate on this issue, one can imagine that a state wishing to recognize a valid same-sex marriage would argue that a strong public policy against discrimination would trigger such an exception. Likewise, a state refusing to recognize same-sex marriage would argue that strong public policies behind encouraging committed opposite-sex marriages, maintaining the traditional definition of marriage, and promoting procreation within the confines of marriage would also trigger the exception. In either case, the situation remains that a privilege recognized in one state may not be recognized in another state.

150. Id. at $237-38$

151. Id. at 240 (internal citations omitted). 
provides that states need not recognize a valid marriage celebrated elsewhere, states are not bound to honor the marriages performed by other states under current law. ${ }^{152}$ With so many states divided over the issue of marriage equality, the risk of these definitions conflicting is on the rise.

\section{A LESSER PRIVILEGE?}

As explained above, a state with a mini-DOMA need not recognize a same-sex marriage celebrated in another state as valid because $\S 2$ of DOMA federally protects states in curtailing those rights. ${ }^{153}$ Without a valid marriage, the courts in those states with mini-DOMAs will not recognize either marital privilege in their courts when asserted by a same-sex spouse. ${ }^{154}$ This reality may have a chilling effect on same-sex spouses in how they communicate even while present in the state which celebrated their marriage. Because "an uncertain privilege ... is little better than no privilege at all,"155 the mini-DOMAs in effect in states other than that in which the same-sex spouses were married essentially prevent those spouses from exercising the rights and privileges afforded them by the state recognizing their marriage. For example, Texas's mini-DOMA may prevent a same-sex couple legally married and residing in New York from communicating freely within New York despite the fact that New York intended to afford same-sex couples all the rights and privileges of marriage, including marital privileges. ${ }^{156}$ In that light, it seems that voters in Texas have devalued the rights of New York citizens, creating an inequality unintended by New York law.

\section{A. Section 2 of DOMA and Mini-DOMAs}

While the Supreme Court struck $\S 3$ of DOMA in United States $v$. Windsor, ${ }^{157}$ that decision had no effect on $\S 2$, which remains a valid statute. In $\S 2$, DOMA states:

\footnotetext{
152. 28 U.S.C. $\S 1738 \mathrm{C}(2012)$.

153. Id.

154. See supra notes 123-24 and accompanying text.

155. Upjohn Co. v. United States, 449 U.S. 383, 393 (1981)

156. See N.Y. Dom. Rel. LAW § 10-a (McKinney 2013) (providing that same-sex couples should have the same access as others to the protections, responsibilities, rights, obligations, and benefits of civil marriage).

157. 133 S. Ct. $2675,2695-96$ (2013).
} 
No State, territory, or possession of the United States, or Indian tribe, shall be required to give effect to any public act, record, or judicial proceeding of any other State, territory, possession, or tribe respecting a relationship between persons of the same sex that is treated as a marriage under the laws of such other State, territory ${ }_{15}$ possession, or tribe, or a right or claim arising from such relationship.

Thus, federal law currently protects state laws modeled after $\S 3$ of DOMA, although the Supreme Court has already ruled $\S 3$ itself unconstitutional. $^{159}$

Currently, mini-DOMAs are under attack in the courts, ${ }^{160}$ and several more have already been ruled unconstitutional by federal district courts, ${ }^{161}$ as well as a state supreme court. ${ }^{162}$ The reasoning of the district courts in each case, resolved post-Windsor, relied on the Supreme Court's analysis that laws prohibiting same-sex marriage violate the Equal Protection Clause, as well as in some cases the Due Process Clause, of the Fifth and Fourteenth Amendments. ${ }^{163}$ Until either Congress repeals or the Supreme Court strikes $\S 2$ of DOMA, or every mini-DOMA is repealed or individually ruled unconstitutional, the situation will remain that a court considering the applicability of marital privileges will have to discern whether a marriage valid in one state is valid in another. ${ }^{164}$

Under a traditional conflict of laws analysis, states should recognize marriages validly celebrated in another state, unless the marriage is an evasive one (one in which the couple leaves their home state to

158. 28 U.S.C. $\S 1738 \mathrm{C}(2012)$.

159. See Windsor, $133 \mathrm{~S}$. Ct. at 2695-96 (holding $\S 3$ of DOMA unconstitutional, but leaving $\S$ 2 in force).

160. See, e.g., Tanco v. Haslam, No. 3:13-CV-01159, 2014 WL 997525, at *9 (M.D. Tenn. Mar. 14, 2014) (granting preliminary injunction preventing State of Tennessee from denying validity of three same-sex marriages validly celebrated out-of-state).

161. See, e.g., Bostic v. Rainey, 970 F. Supp. 2d 456, 484 (E.D. Va. 2014), aff'd, Bostic v. Shaefer, Nos. 14-1167, 14-1169, 14-1173, 2014 WL 3702493 (4th Cir. 2014); Bourke v. Beshear, No. 3:13-CV-750-H, 2014 WL 556729, at*1 (W.D. Ky. Feb. 12, 2014); Bishop v. Unites States ex. rel. Holder, 962 F. Supp. 2d 1252, 1296 (N.D. Okla. 2014), aff'd, Bishop v. Smith, Nos. 14-5003 \& 14-5006, 2014 WL 3537847 (10th Cir. July 18, 2014); Kitchen v. Herbert, 961 F. Supp. 2d 1181, 1188 (D. Utah 2013), aff'd, 755 F.3d 1193 (10th Cir. 2014).

162. See, e.g., Griego v. Oliver, 316 P.3d 865, 889 (N.M. 2013) (striking New Mexico's miniDOMA as violative of the state constitution).

163. See, e.g., Bostic, 970 F. Supp. 2d at 480, 482 (finding violations of Equal Protection and Due Process Clauses); Bourke, 2014 WL 556729, at*3 (finding equal protection violation); Bishop, 962 F. Supp. 2d at 1258 (finding equal protection violation); Kitchen, 961 F. Supp. 2d at 1205, 1215 (finding due process and equal protection violations).

164. See supra Part IV.C. 
temporarily travel to another state to marry because their home state would not otherwise celebrate or recognize their marriage). ${ }^{165}$ The purpose of this "place of celebration rule" is to provide to the couple predictability about their rights and obligations within the marriage. ${ }^{166}$ Mini-DOMAs, however, invoke the "public policy exception" to this place of celebration rule to abandon comity, upending validly celebrated marriages in contravention of the public policy to sustain marriages. ${ }^{167}$

\section{B. An Uncertain Privilege}

The Supreme Court in United States v. Windsor took issue with the fact that $\S 3$ of DOMA sought "to injure the very class New York [sought] to protect." 168 The Court noted that, "[a]fter a statewide deliberative process that enabled its citizens to discuss and weigh arguments for and against same-sex marriage, New York acted to enlarge the definition of marriage to correct what its citizens and elected representatives perceived to be an injustice that they had not earlier known or understood."169 The Court viewed the actions of the Federal Government in enacting $\S 3$ of DOMA as imposing "restrictions and disabilities" on a class of New York citizens "resulting [in] injury and indignity." 170 The Court deemed these actions by the United States to be overstepping the bounds of federalism in violation of the Due Process and Equal Protection Clauses of the Fifth Amendment. ${ }^{171}$

Mini-DOMAs, in effect, do the same thing in violation of the Fourteenth Amendment that $\S 3$ of DOMA did in violation of the Fifth Amendment. ${ }^{172}$ These laws curtail the rights and privileges of same-sex

\footnotetext{
165. Sanders, supra note 2, at 100.

166. Id. at $100-01$.

167. Id. at 101 .

168. United States v. Windsor, 133 S. Ct. 2675, 2693 (2013). "When New York adopted a law to permit same-sex marriage, it sought to eliminate inequality; but DOMA frustrates that objective through a system-wide enactment with no identified connection to any particular area of federal law." Id. at 2694 .

169. Id. at 2689 (citing Marriage Equality Act, 2011 N.Y. Sess. Laws 749 (McKinney) (codified at N.Y. DOM. REL. LAW §§ 10-a, 10-b, 13 (McKinney 2013)).

170. Id. at 2692 .

171. Windsor, 133 S. Ct. at 2695.

172. The two situations are, however, distinguishable in that states are vested with the power to define marriage. See id. at 2692 (2013) (noting states' power to define marriage and the significance of that power). In the example here, we have one state's expansion of marriage abridged by another state's limitation on marriage. This is arguably different from the situation of the federal government overreaching into the law of marriage to create a body of law at odds with the expansive definition of marriage one state, fully entitled to define marriage, has adopted.
} 
spouses lawfully bestowed upon them by a state that intended such rights and privileges to be realized. Returning to the example above, Texas's mini-DOMA limits the exercise of a privilege in New York by New Yorkers, despite the fact that New York intended the New York couple to have unlimited access to the benefits which accompany the marital privileges. The New Yorkers cannot fully embrace "the best solace of human existence" 173 - the intimate exchange of communications with a spouse - in New York, for fear that the privilege will not be recognized in any state with a mini-DOMA. ${ }^{174}$ This is because the New York couple cannot foresee whether either or both spouses will ever be involved in criminal or civil litigation in any one of those states. Without knowing the communications will be protected, the policy behind the privilege is defeated; "[a]n uncertain privilege . . . is little better than no privilege at all." 175

Evidentiary privileges are useless absent certainty and predictability in their application. ${ }^{176}$ "If there is no certainty of application, the

173. Stein v. Bowman, 38 U.S. 209, 223 (1839).

174. A valid argument is made by at least one commentator that the non-existence of a marital communications privilege would have no chilling effect on communications between spouses. See Teachers' Manual to Green, Nesson \& Murray, Problems, Cases, and Materials on Evidence, 3rd Edition: The Husband and Wife Privilege, HARVARD LAw, http://www.law.harvard.edu/ publications/evidenceiii/professorspages/tmch7e.htm (last visited Sept. 20, 2014) (“A marital communications privilege does not materially foster marital communications because many spouses are unaware of its existence and few spouses would hesitate to communicate because of its absence. Any damage to a marriage relationship caused by one spouse testifying against the other would seem to flow from one doing damage to the other, not from one disclosing communications of the other.") This is a logical argument. If courts or legislators, however, believed it to be true, there would be no need for a marital communications privilege in any case. The need for such a privilege, or lack thereof, is beyond the scope of this article. Logical arguments to the contrary aside, I will proceed from the assumption that there exists some positive effect of the marital communications privilege in encouraging intra-marital communications sufficient to justify recognition of such a privilege in all fifty states and the District of Columbia.

175. Upjohn Co. v. United States, 449 U.S. 383, 393 (1981).

176. See, e.g., id. at 393 ("An uncertain privilege, or one which purports to be certain but results in widely varying applications by the courts, is little better than no privilege at all."); Grace M. Giesel, End the Experiment: The Attorney-Client Privilege Should Not Protect Communications in the Allied Lawyer Setting, 95 MARQ. L. Rev. 475, 551 (2012) (discussing how uncertainty in a privilege undermines the purposes of a privilege and renders it ineffective); $i d$. at $551 \mathrm{n} .341$ (quoting Daniel J. Capra, The Attorney-Client Privilege in Common Representations, TRIAL LAW. Q., Summer 1989, at 20,21) ("noting that confusion is costly because "it is crucial for the attorney and client to know at the outset whether proposed communications are within the privilege"'); Katharine T. Schaffzin, An Uncertain Privilege: Why the Common Interest Doctrine Does Not Work and How Uniformity Can Fix It, 15 B.U. PUB. INT. L.J. 49, 65 (2005) (noting that significant uncertainty in the application of a privilege discourages parties from communicating pursuant to the privilege). See also Gregory J. Kopta, Comment, Applying the Attorney-Client Privilege and Work Product Privileges to Allied Party Exchange of Information in California, 36 UCLA L. REV. 151, 153 (1988) (citing Richard L. Marcus, The Perils of Privilege: Waiver and the Litigator, $84 \mathrm{MiCH}$. L. 
privilege has no value because no one can know that a communication is privileged when that communication occurs." "177 If an individual doubts that a confidence will be maintained and protected by a court, then he or she is significantly less like to share communications of consequence. ${ }^{178}$ Because the purpose of the confidential marital communications privilege is to encourage spouses to seek out the comforts of their partners concerning the most significant subjects in their lives, ${ }^{179}$ uncertainty in the maintenance of such confidences would serve to frustrate that goal.

\section{OPTIONS FOR RESTORING CERTAINTY TO MARITAL PRIVILEGES}

As explained above, the only way to ensure that same-sex married citizens may fully enjoy the rights and benefits of marriage within states where their marriages are recognized - including the intimate sharing of confidential communications between spouses-is to ensure that their marriage would be deemed valid by all other states-even those with mini-DOMAs. ${ }^{180}$ Until those individuals can predict that their marriages will be recognized as valid in all fifty states, they should assume that no marital privilege will apply to them in a state with a mini-DOMA, even to protect communications made and marriages celebrated out-of-state. ${ }^{181}$ Without uniform marital privileges, the relationships and communications the recognizing state intended to promote and maintain will instead be inhibited by the laws of other jurisdictions. ${ }^{182}$

To effectuate the intent of those jurisdictions which do extend marital privileges to same-sex spouses, one of two options is needed.

REV. 1605, 1609-17 (1986)) ("Continuing uncertainty exacts a high price. Fear of waiver in general is very expensive to both the participants and the legal system itself.").

177. Giesel, supra note 176, at 551 (citations omitted).

178. See Upjohn, 449 U.S. at 391-93 (stating that uncertainty of privilege applicability will have the effect of decreasing communication between persons who are unsure of whether their communications will be privileged).

179. See Stein v. Bowman, 38 U.S. 209, 223 (1839) ("This rule is founded upon the deepest and soundest principles of our nature. Principles which have grown out of those domestic relations, that constitute the basis of civil society; and which are essential to the enjoyment of that confidence which should subsist between those who are connected by the nearest and dearest relations of life. To break down or impair the great principles which protect the sanctities of husband and wife, would be to destroy the best solace of human existence.").

180. See supra Part V.B.

181. See supra Part V.B.

182. See supra Part V.B. 
First, a uniform marital privilege would provide the predictability needed to enable same-sex couples fostering a family relationship and communications in a state that recognizes their full marital rights to maintain that relationship and strengthen those communications. Second, a ruling from the Supreme Court of the United States that both DOMA and mini-DOMAs are unconstitutional would require states not currently recognizing valid same-sex marriages to do so; in a court's analysis of whether to apply a marital privilege, the conclusion that a valid marriage exists will lead the court to recognize the privilege where it is otherwise available.

\section{A. A Uniform Privilege?}

The first option - a uniform marital privilege - is not a viable solution. Of course, the Supreme Court could promulgate a Federal Rule of Evidence concerning marital privileges. Unfortunately, they tried that in 1972 and Congress then spent three years debating the federal law on privileges before scrapping all rules on privilege in favor of allowing federal common law to govern privileges where federal law provides the rules of decision, and requiring federal courts to apply state law on privileges where state law otherwise applies to the case. ${ }^{183}$ Interestingly, the privilege the Court advanced in 1972 was the spousal immunity privilege; the Court intentionally omitted the confidential marital communications privilege. ${ }^{184}$ Today, not only would our modern Congress have to agree on the extent of the marital privileges covered under a federal rule, they would have to agree to extend it to same-sex couples. Given the divided state of our Congress, it seems highly unlikely that such a scenario could ever play out in the near future.

Besides, a federal rule on privileges would apply only in federal court; to achieve the uniformity needed concerning the recognition of marital privileges to same-sex couples, federal and state courts would all have to adopt a similar privilege extending marital privileges to same-sex couples. In this current political landscape of states characterized as red or blue, achieving unanimity on the issue of extending marital privileges to same-sex spouses is unrealistic. The fact that forty-two states have passed legislation or constitutional amendments to prevent recognition of

183. See Eileen A. Scallen, Proceeding with Caution: Making \& Amending the Federal Rules of Evidence, 36 Sw. U. L. REV. 601, 608-09 (2008) (examining the history of the Federal Rules of Evidence and noting the controversy over the rules concerning privilege).

184. See supra notes $79-85$ and accompanying text. 
same-sex marriages, ${ }^{185}$ further renders a uniform marital privilege impossible.

\section{B. Court Intervention}

That leaves the second option for allowing same-sex partners to fully exercise the benefits associated with marital privileges - intervention by the Supreme Court-as the only viable option for achieving the predictability necessary to resolve the current inequitable application of marital privileges. The Court could rely on any one of a number of arguments to strike both DOMA and mini-DOMAs, including the Equal Protection Clause, ${ }^{186}$ the Due Process Clause, ${ }^{187}$ or the Full Faith and Credit Clause. ${ }^{188}$ Uniformity in the application of marital privileges is not achieved directly, but uniformity in determining the validity of a marriage is, nonetheless, achieved under this option. The privileges could remain as they were under DOMA and mini-DOMAs; the difference would be whether the court finds a valid marriage. In so finding a valid marriage even in the case of a same-sex couple, the privilege would be applied. With that predictability, same-sex partners could then fully exercise the rights and benefits conferred to them by the states celebrating their marriages; they would be free to communicate intimately just like any opposite-sex couple without fear of those communications later being exposed.

\section{Equal Protection Under the Law}

The most successful argument challenging same-sex marriage bans post-United States $v$. Windsor is that such prohibitions violate the Equal Protection Clause of the Fourteenth Amendment. ${ }^{189}$ That clause prohibits any state from denying "to any person within its jurisdiction the

\footnotetext{
185. See supra note 123.

186. See infra Part VI.B.1.

187. See infra Part VI.B.2.

188. See infra Part VI.3.

189. See, e.g., Bostic v. Rainey, 970 F. Supp. 2d 456, 484 (E.D. Va. 2014), aff'd, Bostic v. Schaefer, Nos. 14-1167, 14-1169, 14-1173, 2014 WL 3702493 (4th Cir. Jul. 28, 2014) (finding that Virginia's same-sex marriage ban violates the Fourteenth Amendment); Bourke v. Beshear, No. 3:13-CV-750-H, 2014 WL 556729, at*1 (W.D. Ky. Feb. 12, 2014) (finding that Kentucky's samesex marriage ban violates the Fourteenth Amendment); Bishop, 962 F. Supp. 2d at 1258 (holding that Oklahoma's same-sex marriage ban violates the Fourteenth Amendment); Kitchen v. Herbert, 961 F. Supp. 2d 1181, 1188 (D. Utah 2013), aff'd, 755 F.3d 1193 (10th Cir. 2014) (finding that Utah's same-sex marriage ban violates the Fourteenth Amendment).
} 
equal protection of [its] laws." 190 Where a state law interferes with the exercise of a fundamental right, that law must be closely tailored to effectuate sufficiently important state interests. ${ }^{191}$ Where a fundamental right is not affected, but a class-based equal protection challenge is raised, the court must first ask, "whether the challenged state action intentionally discriminates between groups of persons." 192 Where a finding of intentional discrimination is made, a court must then decide whether the state's discriminatory action is justified by some "upright government purpose."193

Heightened scrutiny of intentional discrimination is warranted where the target of the discrimination is a suspect class. ${ }^{194}$ Legislation that targets classifications based on sex or illegitimacy is subject to intermediate scrutiny, which upholds quasi-suspect classifications only where they are "substantially related to an important governmental objective." 195 All other discriminatory laws are subject to the rational basis test. ${ }^{196}$

While several courts have insinuated that a heightened level of scrutiny should apply to the issue of same-sex marriage, there is no consensus on that issue currently. ${ }^{197}$ Many recent decisions on the matter have, nonetheless, found that same-sex marriage bans do not even satisfy the rational basis test requiring that the state law bear "a rational

190. U.S. CONST. amend. XIV, § 1.

191. Zablocki v. Redhail, 434 U.S. 374, 388 (1978).

192. SECSYS, LLC v. Vigil, 666 F.3d 678, 685 (10th Cir. 2012) (citing Washington v. Davis, 426 U.S. 229, 240 (1976); McCleskey v. Kemp, 481 U.S. 279, 292 (1987); Pers. Adm'r of Mass. V. Feeney, 442 U.S. 256, 272-74 (1999); Snowden v. Hughes, 321 U.S. 1, 8 (1944)).

193. Id. at 686 .

194. See, e.g., Clark v. Jeter, 486 U.S. 456, 461 (1988) (discussing equal protection scrutiny levels); SECSYS, 666 F.3d at 687 (citing Feeney, 442 U.S. at 272-73) (discussing intentional discrimination and equal protection classifications).

195. Clark, 486 U.S. at 461.

196. See, e.g., Reno v. Flores, 507 U.S. 292, 303 (1993) (explaining the need for a rationally related governmental interest); SECSYS, 666 F.3d at 687 (discussing whether discrimination existed for rational reasons).

197. See, e.g., Bostic v. Rainey, 970 F. Supp. 2d 456, 473 (E.D. Va. 2014), aff'd, Bostic v. Shaefer, Nos. 14-1167, 14-1169, 14-1173, 2014 WL 3702493 (4th Cir. July 28, 2014) (finding strict scrutiny should apply because Virginia's laws infringe on a fundamental right and are aimed at a discrete and insular minority); Bourke v. Beshear, No. 3:13-CV-750-H, 2014 WL 556729, at *4-5 (W.D. Ky. July 1, 2014) (stating that "a number of reasons suggest that gay and lesbian individuals do constitute a suspect class," before ultimately applying rational basis review because the Windsor Court "did not clearly state that the non-recognition of marriages under Section 3 of DOMA implicated a fundamental right"); Kitchen v. Herbert, 961 F. Supp. 2d 1181, 1204 (D. Utah 2013), aff'd, 755 F.3d 1193 (10th Cir. 2014) ("The court therefore finds that the Plaintiffs have a fundamental right to marry that protects their choice of a same-sex partner."). 
relationship to some legitimate end." ${ }^{198}$ As explained above, the Supreme Court in Windsor found that the federal definition of marriage found in DOMA $\S 3$ failed the rational basis test. ${ }^{199}$ Since Windsor was decided, several federal courts have also found state mini-DOMAs failing the rational basis test. ${ }^{200}$

In Bostic v. Rainey, the United States District Court for the Eastern District of Virginia held that Virginia's statutory mini-DOMA and constitutional amendment prohibiting same-sex marriage deprived samegender Virginia couples of the fundamental right to marry in violation of the Equal Protection Clause of the Fourteenth Amendment, because those laws were not sufficiently tailored to effectuate only those important state interests. ${ }^{201}$ Moreover, the court held that such laws violate the Equal Protection Clause even absent a finding that the right to marry is a fundamental right because same-sex couples are treated differently under Virginia's laws than opposite-sex couples, although they are similarly situated. ${ }^{202}$ Although the court held that strict scrutiny

198. See, e.g., Bostic, 970 F. Supp. 2d at 482; Bourke, 2014 WL 556729, at *7 (citing Loving v. Virginia, 388 U.S. 1, 12 (2005); Lawrence v. Texas, 538 U.S. 558, 577-78 (2005); Nev. Dep't of Human Res. v. Hibbs, 538 U.S. 721, 733-35 (2003)) ("Over the past forty years, the Supreme Court has refused to allow mere tradition to justify marriage statutes that violate individual liberties."); Bishop v. United States ex rel. Holder, 962 F. Supp. 2d 1252, 1290-95 (N.D. Okla. 2014), aff'd, Bishop v. Smith, Nos. 14-5003 \& 14-5006, 2014 WL 3537847 (10th Cir. July 18, 2014) ("the Court concludes that exclusion of same-sex couples is 'so attenuated' from any of [the state's proffered] goals that the exclusion cannot survive rational-basis review"); Kitchen, 961 F. Supp. 2d at 1206-07 (citing United States v. Virginia, 518 U.S. 515, 533 (2005)) ("[B]ecause the court finds that Amendment 3 fails rational basis review, it need not analyze why Utah is also unable to satisfy the more rigorous standard of demonstrating an 'exceedingly persuasive' justification for its prohibition against same-sex marriage.").

199. 133 S. Ct. 2675, 2695 (2013).

200. Bostic, 970 F. Supp. 2d at 482; Bourke, 2014 WL 556729, at *7; Bishop, 962 F. Supp. 2d at 1290-95; Kitchen, 961 F. Supp. 2d at 1206-07. Notably, the New Mexico Supreme Court has ruled since Windsor that New Mexico's mini-DOMA discriminated against a discrete subclass and failed to pass muster under intermediate scrutiny. Griego v. Oliver, 316 P.3d 865, 889 (N.M. 2013) (striking New Mexico's prohibitions on same-sex marriage as violative of the state Constitution).

201. 970 F. Supp. 2d at 482. The court in Bostic ultimately held Virginia's statutory and constitutional bans on same-sex marriage unconstitutional under the Due Process and Equal Protection Clauses of the Fourteenth Amendment. Id. at 484. In that case, Plaintiffs Timothy Bostic and Tony London were denied a marriage license by the Clerk for the Circuit Court for the City of Norfolk. Id. at 462. They met all the legal requirements for marriage in Virginia, except neither of the applicants was a woman. Id. Plaintiffs Carol Schall and Mary Townley joined the suit challenging the facets of Virginia's marriage laws which refused to recognize the couple's lawful marriage in California, denying them many of the benefits received by opposite-sex married couples in Virginia. Id. at 462-63. Schall and Townley met all legal requirements for recognition of their marriage in Virginia, with the exception that neither is a man. Id. at 462.

202. Id. at 480 . 
applied, it decided that Virginia's same-sex marriage prohibitions fail to pass muster even under the most deferential rational basis test. ${ }^{203}$

In Bourke v. Beshear, the United States District Court for the Western District of Kentucky held Kentucky's statutory and constitutional bans on the recognition of valid same-sex marriages celebrated in foreign states to be unconstitutional under the Equal Protection Clause of the Fourteenth Amendment. ${ }^{204}$ Although the court reasoned (1) that the Supreme Court indicated that heightened review may apply, (2) that the Sixth Circuit Court of Appeals may also apply a heightened standard of review if asked to revisit the issue, and (3) that it strongly believed sexual orientation could be deemed a suspect class warranting heightened review, it ultimately applied only the rational basis test. ${ }^{205}$ Ultimately, the court determined that the proffered purpose for Kentucky's same-sex marriage bans-to preserve the state's institution of traditional marriage-was not a sufficiently legitimate interest to pass constitutional muster under the rational basis test. ${ }^{206}$

The United States District Court for the Northern District of Oklahoma similarly held Oklahoma's constitutional amendment unconstitutional as a violation of the Equal Protection Clause of the Fourteenth Amendment in Bishop v. United States ex rel. Holder, Jr. ${ }^{207}$

203. Id. at 482. "The legitimate purposes proffered by the Proponents for the challenged lawsto promote conformity to the traditions and heritage of a majority of Virginia's citizens, to perpetuate a generally-recognized deference to the state's will pertaining to domestic relations laws, and, finally, to endorse 'responsible reproduction'-share no rational link with Virginia Marriage Laws being challenged. The goal and the result of this legislation is to deprive Virginia's gay and lesbian citizens of the opportunity and right to choose to celebrate, in marriage, a loving, rewarding, monogamous relationship with a partner to whom they are committed for life. These results occur without furthering any legitimate state purpose." Id.

204. 2014 WL 556729, at*1. Beshear involved claims brought by homosexual Kentucky citizens, validly married outside Kentucky, and their children, challenging the constitutionality of Kentucky's mini-DOMA. Id. at*2.

205. Id. at *4-5. "So, we are left without a clear answer.... Therefore, the Court will apply rational basis review. Ultimately, the result in this case is unaffected by the level of scrutiny applied." Id.

206. Id. at *7 (citing Loving v. Virginia, 388 U.S. 1, 12 (2005); Lawrence v. Texas, 538 U.S. 558, 577-78 (2005); Nev. Dep't of Human Res. v. Hibbs, 538 U.S. 721, $733-35$ (2003)) ("Over the past forty years, the Supreme Court has refused to allow mere tradition to justify marriage statutes that violate individual liberties.").

207. 962 F. Supp. 2d 1252, 1296 (N.D. Okla. 2014), aff'd, Bishop v. Smith, Nos. 14-5003 \& 145006, 2014 WL 3537847 (10th Cir. July 18, 2014). In Bishop, Susan Barton and Gay Phillips, lesbian Oklahoma residents legally married in both Canada and California, sued Sally Howe Smith, Court Clerk for Tulsa Oklahoma, alleging among other things that Oklahoma's mini-DOMA violated their substantive due process rights and the Equal Protection Clause of the Fourteenth Amendment. Id. at 1262. Mary Bishop and Sharon Baldwin, also lesbian Oklahoma residents, alleged similar claims after their application for a marriage license was denied. Id. at 1263. After 
The court described the intentional discrimination in Oklahoma's miniDOMA to be "stark," noting that "[i]ts effect is to prevent every samesex couple in Oklahoma from receiving a marriage license, and no other couple."208 The court found further evidence of intentional discrimination in the public comments of Oklahoma legislators at the time of the laws passage. ${ }^{209}$ After determining that class-based discrimination against same-sex couples was not entitled to heightened scrutiny, ${ }^{210}$ the court found that none of the justifications for Oklahoma's mini-DOMA - to promote morality, to encourage responsible procreation, to steer procreative relationships to marriage, to promote the traditional nuclear family, and to maintain the traditional definition of marriage - satisfied the rational basis test. ${ }^{211}$

In Kitchen v. Herbert, the U.S. District Court for the District of Utah held Utah's mini-DOMA violative of both the Equal Protection and Due Process Clauses of the Fourteenth Amendment. ${ }^{212}$ The court determined that the right to marry was a fundamental right requiring strict scrutiny. ${ }^{213}$ It further found strict scrutiny implicated because Utah's prohibitions on same-sex marriage involved a sex-based classification. ${ }^{214}$ Nonetheless, the court ultimately decided the matter by finding that Utah's bans on same-sex marriage failed even the rational basis test. ${ }^{215}$

determining that the Barton couple lacked standing to sue the clerk, the court noted that, but for their sexual orientation, the Bishop couple met all the legal requirements for a marriage license in Oklahoma. Id. at 1274-75.

208. Id. at 1282. "[T] $[$ his is a classic, class-based equal protection case in which a line was purposefully drawn between two groups of Oklahoma citizens-same-sex couples desiring an Oklahoma marriage license and opposite-sex couples desiring an Oklahoma marriage license." Id. at 1285 .

209. Id. at $1282-83$.

210. Id. at 1287.

211. Id. at 1290-95 ("the Court concludes that exclusion of same-sex couples is 'so attenuated" from any of [the state's proffered] goals that the exclusion cannot survive rational-basis review").

212. 961 F. Supp. 2d 1181, 1205, 1215 (D. Utah 2013), aff'd, 755 F.3d 1193 (10th Cir. 2014). In Kitchen, two same-sex couples wishing to marry were denied a marriage license, and a third couple was denied recognition of their marriage validly celebrated in Iowa. Id. at 1188-90. They challenged the constitutionality of Utah's mini-DOMA and similar statutes under both the Due Process and Equal Protection Clauses of the Fourteenth Amendment. Id. at 1187.

213. Id. at 1200 .

214. Id. at 1206 ("Applying the same logic [of Loving v. Virginia], the court finds that the fact of equal application to both men and women does not immunize Utah's Amendment 3 from the heightened burden of justification that the Fourteenth Amendment requires of state laws drawn according to sex.").

215. Id. at 1211,1214 (finding that the "[s]tate's interest in responsible procreation and optimal child-rearing" are not furthered by "prohibiting same-sex couples from marrying"). 
Applying the Equal Protection arguments accepted by several federal courts considering the constitutionality of DOMA and mini-DOMAs post-Windsor to the specific example of same-sex marital privileges leads to the conclusion that those laws allowing states to refuse to recognize valid same-sex marriages celebrated in other states are similarly unconstitutional.

While the right to marry is a fundamental right, ${ }^{216}$ and at least a few courts have held the right to marry a person of the same-sex is also a fundamental right, ${ }^{217}$ there is little support for an argument that the recognition of a marital privilege is a fundamental right. A marital privilege is just that, a privilege. Thus, one would be hard-pressed to make the argument that heightened scrutiny should apply where a state refuses to apply an otherwise available marital privilege to a same-sex couple because the couple was being denied a fundamental right.

Arguably, however, heightened scrutiny could apply where a state refuses to extend a marital privilege to a same-sex couple on the basis of animus. A few courts considering a similar issue post-Windsor have found that the purpose of DOMA and mini-DOMAs was to intentionally discriminate against a discrete minority. ${ }^{218}$ The purpose behind refusing to recognize a marital privilege available to similarly situated oppositesex couples also demonstrates animus. Such animus triggers heightened scrutiny, requiring the proponent of the law to show that the law is narrowly tailored to achieve a significant governmental objective. ${ }^{219}$

In the case of marital privileges, DOMA and mini-DOMAs fail to survive heightened scrutiny on both fronts. First, many federal courts considering prohibitions on same-sex marriage post-Windsor have found no significant governmental objective related to denying the validity of same-sex marriages. ${ }^{220}$ Second, the law is certainly not narrowly tailored to achieve any of those objectives argued in support of mini-DOMAs.

216. See, e.g., M.L.B. v. S.L.J. ex rel. S.L.J. \& L.J., 519 U.S. 102, 116 (1996); Planned Parenthood of Se. Pa. v. Casey, 505 U.S. 833, 848 (1992); Turner v. Safley, 482 U.S. 78, 95-96 (1987); Zablocki v. Redhail, 434 U.S. 374, 383-84 (1978).

217. E.g., Bostic v. Rainey, 970 F. Supp. 2d 456, 483 (E.D. Va. 2014), aff'd, Bostic v. Shaefer, Nos. 14-1167, 14-1169, 14-1173, 2014 WL 3702493 (4th Cir. 2014); Kitchen, 961 F. Supp. 2d at 1204.

218. E.g., Bostic, 970 F. Supp. 2d at 482; Bishop v. Unites States ex rel. Holder, 962 F. Supp. 2d 1252, at 1282-85 (N.D. Okla. 2014), aff'd, Bishop v. Smith, Nos. 14-5003, 14-5006, 2014 WL 3537847 (10th Cir. 2014).

219. See, e.g., Bostic, 970 F. Supp. 2 d at 473 (stating that regulations impacting fundamental rights must be "narrowly tailored to serve a compelling state interest").

220. See Bostic, 970 F. Supp. 2d at 482; Bishop, 962 F. Supp. 2d at 1296; Kitchen, 961 F. Supp. $2 \mathrm{~d}$ at 1215 . 
For example, the laws ban recognition of all same-sex marriages; a law narrowly tailored to protect the interests in procreation (a discredited objective) would prohibit same-sex couples from legally adopting children, rather than prevent couples from sharing their lives together. These laws fail under heightened scrutiny.

Nonetheless, many courts considering the validity of mini-DOMAs post-Windsor have applied the rational basis test finding that, even under this test that is most deferential to state law, mini-DOMAs frustrate the Equal Protection Clause. ${ }^{221}$ When considering a court's refusal to apply a marital privilege to a same-sex couple validly married in another state, such actions also fail the rational basis test. As noted by so many courts post-Windsor, there is no legitimate purpose for denying the right to marry to same-sex partners; ${ }^{22}$ similarly, there is no legitimate purpose for denying marital privileges to validly married same-sex partners when such privileges are available to their opposite-sex counterparts. And, as explained by those courts, there exists no rational relationship between prohibiting same-sex marriage and encouraging procreation, encouraging marriage, or any of the other objectives advanced by defenders of miniDOMAs. $^{223}$ Similarly, there is no rational relationship between denying the marital privileges to same-sex spouses and any of those objectives advanced. For these reasons, the denial of marital privileges to same-sex spouses violates their equal protection rights.

\section{Substantive Due Process}

Some courts considering the constitutionality of mini-DOMAs postWindsor have found such laws to also violate the Due Process Clause of the Fourteenth Amendment. ${ }^{224}$ The Fourteenth Amendment to the U.S. Constitution provides:

221. See, e.g., Bostic, 970 F. Supp. 2d at 478; Bourke v. Beshear, 996 F. Supp .2d 542, 544 (W.D. Ky. 2014); Bishop, 962 F. Supp. 2d at 1295; Kitchen, 961 F. Supp. 2d at 1205.

222. See supra note 221.

223. See, e.g., Bostic, 970 F. Supp. 2d at 482 ("Virginia's Marriage Laws fail to display a rational relationship to a legitimate purpose, and so must be viewed as constitutionally infirm under even the least onerous level of scrutiny."); Bourke, 996 F. Supp. 2d at 553 ("the Court cannot conceive of any reasons for enacting the laws challenged here.”); Bishop, 962 F. Supp. 2d at 1295 ("Having considered all four proffered justifications for Part A, the Court concludes that exclusion of same-sex couples is 'so attenuated' from any of these goals that the exclusion cannot survive rational-basis review."); Kitchen, 961 F. Supp. 2d at 1205 ("the State of Utah has not demonstrated a rational, much less a compelling, reason why the Plaintiffs should be denied their right to marry.").

224. E.g., Bostic, 970 F. Supp. 2d at 484; Kitchen, 961 F. Supp. 2d at 1205. 
No State shall make or enforce any law which shall abridge the privileges or immunities of citizens of the United States; nor shall any State deprive any person of life, liberty, or property, without due process of law; nor deny to any person within its jurisdiction the equal protection of the laws.

It applies not only to procedural matters but to those involving substantive law, as well. ${ }^{226}$ "Thus all fundamental rights comprised within the term liberty are protected by the Federal Constitution from invasion by the States.",227

In determining whether a state law violates the substantive due process rights of a U.S. citizen, a court must first determine if the plaintiff seeks protection of a fundamental right and, next, whether the state law improperly compromises that fundamental right. ${ }^{228}$ "There can be no serious doubt that in America the right to marry is a rigorously protected fundamental right. The Supreme Court has recognized repeatedly that marriage is a fundamental right protected by both the Due Process and Equal Protection Clauses of the Fourteenth Amendment.",229

In Bostic v. Rainey, the United States District Court for the Eastern District of Virginia held that Virginia's statutory mini-DOMA and constitutional amendment prohibiting same-sex marriage deprived lesbian, gay, bisexual, and transgender Virginia citizens of the fundamental right to marry in violation of the Due Process Clause of the Fourteenth Amendment. ${ }^{230}$ In Kitchen v. Herbert, the United States District Court for the District of Utah similarly found Utah's miniDOMA violated the fundamental right to marry in violation of the Due

\footnotetext{
225. U.S. CONST. amend. XIV, § 1.

226. See Planned Parenthood of Se. Pa. v. Casey, 505 U.S. 833, 846-47 (1992) (quoting Whitney v. California, 274 U.S. 357, 373 (1927) (Brandeis, J., concurring)) (" $[1]$ t is settled that the due process clause of the Fourteenth Amendment applies to matters of substantive law as well as to matters of procedure.").

227. Id. at 847 (quoting Whitney, 274 U.S. at 373 (Brandeis, J., concurring)).

228. Bostic, 970 F. Supp. 2 d at 470.

229. Id. at 470-71 (citing M.L.B. v. S.L.J. ex rel. S.L.J. \& L.J, 519 U.S. 102, 116 (1996); Casey, 505 U.S. at 848; Turner v. Safley, 482 U.S. 78, 97 (1987); Zablocki v. Redhail, 434 U.S. 374, $383-$ 84 (1978); Carey v. Population Servs. Int'l, 431 U.S. 678, 684-85 (1977); United States v. Kras, 409 U.S. 434, 446 (1973); Boddie v. Connecticut, 401 U.S. 371, 376 (1971); Loving v. Virginia, 388 U.S. 1, 12 (1967); Griswold v. Connecticut, 381 U.S. 479, 486 (1965); Skinner v. Oklahoma ex rel. Williamson, 316 U.S. 535, 541 (1942); Meyer v. Nebraska, 262 U.S. 390, 399 (1923); Andrews v. Andrews, 188 U.S. 14, 30 (1903); Maynard v. Hill, 125 U.S. 190, 205 (1888), abrogated on other grounds, Sherrer v. Sherrer, 334 U.S. 343, 352 (1948)).

230. See Bostic, 970 F. Supp. 2d at 484 (holding Virginia's statutory and constitutional bans on same-sex marriage unconstitutional under both the Due Process and Equal Protection Clauses).
} 
Process Clause. ${ }^{231}$ The court in Kitchen noted that the right to a samesex marriage was not a new right compared to the right to opposite-sex marriage, just as the United States Supreme Court did not distinguish the right to an interracial marriage from the right to an intraracial marriage in Loving $v$. Virginia. ${ }^{232}$

Finally, a court that has determined that a state law infringes on a fundamental right must apply strict scrutiny to evaluate the constitutionality of the state law. ${ }^{233}$ Strict scrutiny requires that such state laws be narrowly tailored to serve a compelling state interest. ${ }^{234}$ In Bostic v. Rainey, the Eastern District of Virginia held that preserving the tradition of opposite sex marriage fails a strict scrutiny or even rational basis analysis. ${ }^{235}$ That court also held that the justifications for the prohibition of same-sex marriage relating to federalism ${ }^{236}$ and optimal child rearing similarly failed to pass muster under either strict scrutiny or rational basis analysis. ${ }^{237}$ In Kitchen v. Herbert, the U.S. District Court for the District of Utah found that the purposes behind Utah's same-sex

231. See Kitchen v. Herbert, 961 F. Supp. 2d 1181, 1211 (D. Utah 2013), aff'd, 755 F.3d 1193 (10th Cir. 2014) ("[T]he court finds that the legitimate government interests that Utah cites are not rationally related to Utah's prohibition of same-sex marriage.").

232. Id. at 1202 ("Instead of declaring a new right to interracial marriage [in Loving v. Virginia], the Court held that individuals could not be restricted from exercising their existing right to marry on account of the race of their chosen partner. [Loving v. Virginia, 388 U.S. 1, 12 (1967).] Similarly, the Plaintiffs here do not seek a new right to same-sex marriage, but instead ask the court to hold that the State cannot prohibit them from exercising their existing right to marry on account of the sex of their chosen partner.").

233. See, e.g., Washington v. Glucksberg, 521 U.S. 702, 721 (1997) (emphasis in original) (quoting Reno v. Flores, 507 U.S. 292, 302 (1993)) ("the Fourteenth Amendment 'forbids the government to infringe ... fundamental liberty interests at all, no matter what process is provided, unless the infringement is narrowly tailored to serve a compelling state interest."'); Kitchen, $961 \mathrm{~F}$. Supp. $2 \mathrm{~d}$ at 1210 (stating that a burden on a fundamental right requires the standard of strict scrutiny).

234. See, e.g., Glucksberg, 521 U.S. at 721; Zablocki, 434 U.S. at 388.

235. 970 F. Supp. $2 d$ at 474 ("This proffer lacks any rational basis. Virginia's purported interest in minimizing marriage fraud is in no way furthered by excluding one segment of the Commonwealth's population from the right to marry based upon that segment's sexual orientation."). "[T] radition alone cannot justify denying same-sex couples the right to marry any more than it could justify Virginia's ban on interracial marriage." Id. at 475.

236. Id. at 475-77 (same-sex marriage ban proponents asserted "that Virginia maintains a significant interest in reserving the power to regulate essential state matters, and to shield the exercise of that power from intrusive, improper federal interference," but the court stated that such state powers are limited by the Constitution). "[F]ederal courts have intervened, properly, when state regulations have infringed upon the right to marry." $I d$. at 476.

237. Id. at 478. ("Of course the welfare of our children is a legitimate state interest. However, limiting marriage to opposite-sex couples fails to further this interest. Instead, needlessly stigmatizing and humiliating children who are being raised by the loving couples targeted by Virginia's Marriage Laws betrays that interest."). 
marriage bans fail not only strict scrutiny, but the rational basis test as well. ${ }^{238}$

Defining the issue broadly, the denial of a marital privilege to a same-sex couple, although such a privilege would be available to a similarly situated opposite-sex couple, involves the denial of the fundamental right to marry. This would trigger strict scrutiny. ${ }^{239}$ However, narrowly defined, the issue involves the denial of a privilegea marital privilege - not a fundamental right. From this perspective, a court would have a more difficult time finding the violation of a fundamental right where a marital privilege is denied. Thus, the denial of marital privileges does not strongly support a finding that miniDOMAs violate the Due Process Clause.

\section{Comity}

Interestingly, neither the Supreme Court nor any federal Circuit Court has ever weighed into the debate of whether marriage laws are subject to the Full Faith and Credit Clause. ${ }^{240}$ The Full Faith and Credit Clause provides that "Full Faith and Credit shall be given in each State to the public Acts, Records, and judicial Proceedings of every other State." ${ }^{241}$ The Supreme Court interpreted that clause in Magnolia Petroleum Co. v. Hunt, explaining that without the Full Faith and Credit Clause, the states would be "foreign sovereignties, each free to ignore rights and obligations" of the others; ${ }^{242}$ under the clause, it seems, states are required to respect the rights and obligations created under the laws of the others. At least one commentator has suggested "the applicability of full faith and credit to the interstate recognition of marriage seems appropriate and sensible."243

This view, however, contradicts the commonly accepted principle that the Full Faith and Credit Clause is "irrelevant to the question of whether one state must recognize another state's marriage." ${ }^{244}$ When dealing with ordinary statutory acts, the Supreme Court has decided that

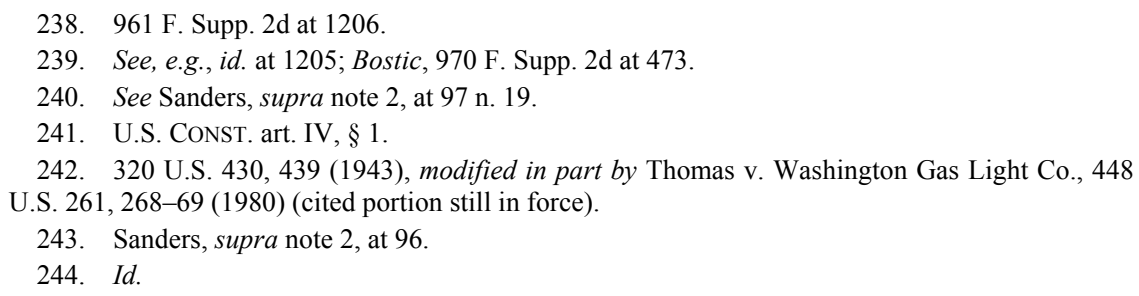


one state is not required to "substitute the statutes of other states for its own statutes dealing with a subject matter concerning which it is competent to legislate." ${ }^{245}$ Because marriage laws are reserved exclusively to the states, ${ }^{246}$ commentators have consistently treated marriage laws as acts not subject to the Full Faith and Credit Clause. ${ }^{247}$ The federal courts have never weighed in on this issue. ${ }^{248}$

The argument in favor of invoking the Full Faith and Credit Clause to strike DOMA $\S 2$, as well as all mini-DOMAs, explains that, unlike workers' compensation laws, drivers' licenses, and fishing licenses, which are all treated as "Acts" not subject to comity principles, ${ }^{249}$ marriage licensing involves a fundamental right protected by the U.S. Constitution. $^{250}$ The Supreme Court has on many occasions singled out marriage as a distinct and special right. ${ }^{251}$ There is no reason to believe that the Court, if given the chance, would not agree that uniformity in marriage is exactly the kind of uniformity the Full Faith and Credit Clause was intended to promote. ${ }^{252}$ A lack of uniformity in marriage licensing can have disastrous results. ${ }^{253}$ For example, a same-sex couple with joint parenting rights in one state may have those parental rights torn asunder by moving across state lines to a state with a mini-DOMA that invalidates the marriage. ${ }^{254}$ One half of a couple seeking a divorce could relocate to a state with a mini-DOMA which would view the marriage as void, even absent a divorce decree. ${ }^{255}$ The list of complications goes on and suggests that this lack of uniformity will have disastrous consequences for same-sex couples seeking to relocate-

245. Baker v. General Motors Corp., 522 U.S. 222, 232 (1998) (quoting Pac. Emp'rs Ins. Co. v. Indus. Accident Comm'n, 306 U.S. 493, 501 (1939) and citing Phillips Petroleum Co. v. Shutts, 472 U.S. 797, 818-19 (1985)). See also, e.g., Sanders, supra note 2, at 96; Mark D. Rosen, Why the Defense of Marriage Act is Not (Yet?) Unconstitutional: Lawrence, Full Faith and Credit, and the Many Societal Actors That Determine What the Constitution Requires, 90 MINN. L. REV. 915, 933 (2006).

246. Trammel v. United States, 445 U.S. 40, 50 (1980).

247. See, e.g., Sanders, supra note 2, at 96; Rosen, supra note 245, at 933, 985.

248. Sanders, supra note 2, at $97 \&$ n. 19.

249. See id. at 104 (discussing the differences between public acts and marriage laws).

250. See id. at 105-06.

251. See id. at 104-05.

252. See id. at 104 .

253. See id. at $95-96$.

254. See id. at 95-96 ("mini-DOMAs effectively nullify the marriages of same-sex couples who migrate from one state to another").

255. See id. 
which is exactly what the Full Faith and Credit Clause was meant to prevent. ${ }^{256}$

With very few federal cases addressing the issue of the applicability of the Full Faith and Credit Clause to marriages, it is anyone's guess as to whether the Supreme Court would entertain such an argument. Many federal courts addressing the validity of DOMA $\S 2$ and mini-DOMAs since United States $v$. Windsor have found a violation of the Equal Protection Clause. ${ }^{257}$ Federal courts have also found violations of the Due Process Clause of the Fourteenth Amendment. ${ }^{258}$ None of these courts addressed the role of the Full Faith and Credit Clause in the discussion. Thus, it is unlikely that the comity issue will reach the Supreme Court before the Court eventually strikes DOMA $\S 2$ and rules state mini-DOMAs similarly unconstitutional on Equal Protection Clause grounds.

The Full Faith and Credit Clause is an excellent, although unpredictable, vehicle for challenging the constitutionality of miniDOMAs that force courts to deny an otherwise applicable marital privilege to a same-sex couple. Promoting uniformity is at the heart of the Full Faith and Credit Clause, ${ }^{259}$ and the lack of uniformity concerning the recognition of marital privileges for same-sex couples is exactly what prevents them from receiving the full rights, privileges, and benefits of marriage that the state of their marriage celebration intended them to have. A same-sex couple validly married in one state cannot enjoy the full privileges and benefits of that marriage- "the best solace of human existence"260 -because the marital privileges to which the couple is entitled in their state of celebration may not be applied by a state with a mini-DOMA because of their gender. Their most prudent course of action is to not fully utilize the privileges extended to them because they may later be forced to reveal confidences in foreign courtrooms to the detriment of their spouses. A state with a mini-DOMA is preventing same-sex couples from fully enjoying their rights when not even located

256. Id. at 110 .

257. E.g., Bostic v. Rainey, 970 F. Supp. 2d 456, 480 (E.D. Va. 2014), aff'd, Bostic v. Shaefer, Nos. 14-1167, 14-1169, 14-1173, 2014 WL 3702493 (4th Cir. 2014); Bourke v. Beshear, No. 3:13CV-750-H, 2014 WL 556729, at*1, 7 (W.D. Ky. Feb. 12, 2014); Bishop v. United States ex rel. Holder, 962 F. Supp. 2d 1252, 1296 (N.D. Okla. 2014), aff'd, Bishop v. Smith, Nos. 14-5003, 145006, 2014 WL 3537847 (10th Cir. 2014); Kitchen v. Herbert, 961 F. Supp. 2d 1181, 1216 (D. Utah 2013), aff'd, 755 F.3d 1193 (10th Cir. 2014).

258. E.g., Bostic, 970 F. Supp. 2d at 484; Kitchen, 961 F. Supp. 2d at 1216.

259. See Sanders, supra note 2, at 110.

260. Stein v. Bowman, 38 U.S. 209, 223 (1839). 
within the state with the mini-DOMA. That state is reaching across its borders to strip citizens from foreign states that do recognize same-sex marriages of their rights. Surely, this is the type of uniformity the Full Faith and Credit Clause was meant to protect. Thus, it should be invoked to challenge the constitutionality of DOMA and mini-DOMAs.

\section{CONCLUSION}

The current divide across states over marriage equality results in the unfortunate side-effect of chilling the exercise of benefits associated with marital privileges by married same-sex couples. Specifically, same-sex couples may not fully engage in the intimate and confidential communications associated with marriage under stressful circumstances without the certainty that those confidences will not later be revealed under court order in a foreign jurisdiction which refuses to recognize the marital privilege for a same-sex couple whose marriage the foreign court rules invalid. This reality allows those states with prohibitions on samesex marriage - or mini-DOMAs - to curtail the rights of same-sex couples residing in foreign jurisdictions, frustrating the intent of the jurisdiction granting the couple all the rights and benefits of marriage.

The only way to resolve this inequity in recognition of marital privileges is to provide certainty in marital privileges. Because a uniform marital privilege is not a viable option, the only way to provide such certainty is through court intervention striking $\S 2$ of DOMA and mini-DOMAs as violative of the Fifth and Fourteenth Amendments, respectively. The best arguments for challenging these laws are the Equal Protection and Full Faith and Credit Clauses. Under the Equal Protection Clause, the unequal application of marital privileges to samesex spouses fails the rational basis test. Under the Full Faith and Credit Clause, mini-DOMAs deny the comity required by the Constitution.

Court intervention to render DOMA $\S 2$ and mini-DOMAs unconstitutional will require states considering the applicability of marital privileges to find a valid marriage on which to base the privilege, even in the case of a same-sex marriage. Predictability in defining a valid marriage across jurisdictions will provide the certainty needed to encourage same-sex couples to fully exercise the rights and privileges of marriage, including the protection of confidentiality in intimate spousal communications and the freedom from testifying adversely to one's spouse. 